Mirjana Vojvoda

Archaeological Institute, Belgrade

mirjana@drenik.net

Milica Tapavički - Ilić

Archaeological Institute, Belgrade
UDK 904:737.1.032.044(37)"'-00/02"

Original research article

Received: March 03, 2010

Accepted:August 02, 2010

\title{
PROVINCIA CAPTA AND PROVINCIA FIDA ET PACATA AS REVERSE MOTIVES ON ROMAN IMPERIAL COINS FROM THE TIME OF PRINCIPATE
}

\begin{abstract}
One group of reverse images showing relationships of Romans with occupied tribes included into the state provincial system shows pictures of defeated tribes. Two groups can be sorted out: the first one (capta) shows Roman victories and conquering of new territories; the second one (fida et pacata) is a group showing personifications of pacified and more or less Romanized provinces. Pictures of province personifications illustrate a conception about the Roman world and inner state policy built by specific emperors. Using coins as a powerful mean of propaganda, emperors advertised their ideas, trying to modell a user's way of thinking in an adequate way.
\end{abstract}

\section{Key WORds: Principate, ReVerse images, Provinces.}

Images on Roman imperial coins represented a powerful mean of propaganda among the contemporaries, whom the emperors wanted to show the highlights of their rule. A need for using coins as a mean of payment, the speed of their production, big amount and currency were advantages compared to other advertising means. On the other hand, a great variety of reverse types offered a possibility to influence practically every segment of the society. By analyzing the frequency of reverse types from the rulers of the late Republic and later emperors during the principate one can realize that the strongest mechanism of ideological influence, through advertising on coins, was directed towards the army, as the main support of power.

At the end of 2nd century, Roman expansion policy led to major changes in the organization of the state and army. On one hand, the Roman state became the greatest empire in the Mediterranean, spreading on three continents. At the same time, on the other hand, the social layer of farmers was destroyed, poverty grew, and the power was concentrated in the hands of the optimates, leading the existing system to a serious and long lasting crisis. During 1 st century B.C, the authority of military

* The article results from the project: Viminacium, Roman city and military legion camp - research of material and non material of inhabitants by using the modern technologies of remote detection, geophysics, GIS, digitalisation and $3 D$ visualisation (no 47018), funded by Ministry of Education and Science of the Republic of Serbia. 
leaders grew enormously due to their victories and division of land and money. Popularity of leaders was supported with his personal qualities but also with the fact that he was chosen and under protection of a deity. In the eyes of soldiers, all of this turned the person of a military commander into a charismatic leader. Soldiers were prepared to support such a leader not only during wars, but also his political ambitions in the inner policy. Since then, connections of soldiers with the civitas grew weaker, and at the same time, their dependence on leaders grew stronger. The connection between the traditional understanding of "soldier" and "citizen" was broken (Абрамзон 1995: 101). The idea of concentrated power in the hands of military leadres became popular among soldiers, offering a perspective of sigle rule among leaders. Still, even after the establishment of single rule, moral values were kept preserved for a long time, in the traditional understanding of res publica and libertas. Of course, they needed to be adapted accoridng to new social and political circumstances. The earlier archetype of an ideal Roman, a man, based on the mos maiorum, showing earned hegemony of the oligarchs and the web of law, duties and moral obligatories, binding citizent to the state - also needed to be adapted (Santosuosso 2004: 23).

Generally, reverse motives are an interesting historical source, offering a detailled studying of aspects of inner and foreign affairs. One group of reverse motives showing relationships of Romans with conquered nations included into the system of the state are personifications of provinces. In course of time, these motives go through different phases, from capta to fidem, from conquered and still unpacified to romanized and incorporated into the administrative, military and politic life of the Empire. According to that, we can separate two groups of reverse motives on coins: the first one (capta) illustrates Roman victories and conquering of new territories; the second (fida et pacata) group includes personifications of pacified and more or less romanized provinces.

\section{PROVINCIA CAPTA}

Motives of trophies and captives can be ascribed to this group, as well as motives of the emperor and the captives. They are mostly represented with stereotype iconographic shemes showing captured trophies and captives or the emperor himslef and representatives of captioned nations, who kneel humiliated infront of the powerfull conqueror. The motives mentioned appear on reverse sides of coins as a result of triumph reached due to the virtues of the emperor himself and to power and capability of the Roman army. ${ }^{1}$ The captives represent personifications of conquered nations or rebelling provinces. Each of these personifications is determined with attributes in shapes of national clothes and weapons or animals and plants typical for this region. ${ }^{2}$ Although there were attempts to canonize personifications of provinces, they mostly referred to specific time periods and were never completely traditionalized.

The first motives representing captured nations occured on Caesar's coins and later on the coins of Marcus Antonius at the end of the Republic. As a revesre motive of Caesar's denar from 48-47 B.C. there is an image of a trophy with a Gallic shield and a battle-trumphet (carnyx), on foot of which there is a long haired and bearded Gaul with hands tied behind his back (Fig. 1) (RRC I: 467, no. 452/4). ${ }^{3}$ On the reverse side of Marcus Antonius denar there is an Armenian tiara, a symbol of Armenian kings, under which there

1 Motives and legends on coins are connected to propagand idea and are complementary to one another. Legends are often there not to explain the motive, but to spread the idea depicted. This is how we find examples of Augustus' mintings on with Victoria is depicted connected with the legends ASIA RECEPTA (RIC I: 61, no. 276) and ARMENIA CAPTA (RIC I: 83, no. 514). As it is stated in the text body, the images from the group provincia capta are closely connected with other motives connected with victories won, which would not be the matter of discussion here

2 For example: palm-trees are connected with Judaea, spear and a hexagonal shield with Germania, bowed sword with Dacia, bow, quiver and tiara for Armenia etc.

3 Illustration taken from Burns and Overbeck1987: 35, cat. 65 . 
are bow and arrows in a quiver, tending to represent Armenians as a militant nation (Fig. 2) (RRC I: 537, no. 539/1; RRC II: 743). ${ }^{4}$ It was minted after Anthony's ,victory“ in Armenia in 36 B.C., after which a gloriuos triumph was celebrated in Alexandria in 34 B.C. (CAH X: 76-80, 82). ${ }^{5}$ On another example of Anthony's minting from 32 B. C. there are Armenian symbols. The legend is ANTONI ARMENIA DEVICTA and Marcus Antonius bust is depicted with an Armenian tiara behind it (RRC I: 539, no. 543/1; RRC II: 743). ${ }^{6}$

The Actium victory, which specified not only Augustus' career, but also destiny of the whole Roman state, takes a specific place in his minting and was shown on different motives on coins. Directly connected with this is also the conquering of Egypt and its turning into a Roman province. On coins, this event was depicted simbolically, with Egypt incorporated into the images of a crocodile and a hippo, with the legend AEGIPTO CAPTA (Fig. 3) (RIC I: 61, no. 275; 86 , nos. 544-546). ${ }^{7}$ In minting propaganda, most attention was given to Augustus' diplomatic success in solving problems with Armenia and Parthia, which, as we can see on coins, was depicted just like any other victory won with weapons. ${ }^{8}$ In

4 Illustration taken from RRC Pl. LXIV, 539/1.

5 In the first campaign against Parthia in 36 B.C. Marcus Antonius chose the way over Armenian mountains, did not show much success and returned with great losses; the second campaign in 34 B.C. was limited to Armenia, where he did not even meet any resistance.

6 Naturally, this was rather shocking for the Roman public, just as much as Cleopatra's image on the reverse side of this coin with a ship bow, along with an enigmatic legend CLEOPATRAE REFINAE REGVM FILIORVM REGVM. Grant even states that there were opinions that one was here dealing with propaganda of the opposite side, since Cleopatra was not depicted in a nice manner (Grant 1958: 46-47). About details on Armenian symbols depicted on mints of Marcus Antonius, Augustus and Marcus Aurelius cf. Matevosyan 2000: 27-32.

7 Illustration taken from BMC I, P1. 16.1.

8 The dispute between Rome and Parthia dates from the time of Pompeius' actions in the East and it got worse after the interventions of Crassus and Marcus Antonius. But there was a permanent reason for mutual animosity and that was the Roman protectorate over Armenia. Augustus
18 B.C., Augustus mints coins with the legend CAESAR AVGVSTVS SIGN RECE, celebrating re-capturing of previously lost Roman standards. A bearded Parthian is depicted, dressed in traditional clothes, kneeling and humiliately giving away the military insignia (Fig. 4) (RIC I: 62, no. 287). ${ }^{9}$ In this series there is also a minting with the legend CAESAR DIVI F ARME CAPT and the image of an Armenian, dressed in a national costume with a tiara on his head, kneeling with his ams stretched in an obedient gesture, expressing the actual position of his country, which on the other hand confirms the Roman domination by crowning a vasal king in Armenia (Fig. 5) (RIC I: 62 , no. 290$).{ }^{10}$ On the same occasion, coins with a tiara, bow and a quiver motive were minted, traditional Armenian symbols, with the legend ARMENIA CAPTA (RIC I: 83, no. 515) or ARMENIA RECEPTA (Fig. 6) (RIC I: 83, no. 517), ${ }^{11}$ along with an image of an Armenian standing frontally and wearing a cloak, a spear in his right hand and leaning his left on a bow, with the legend CAESAR DIVI F ARMEN CAPTA IMP VIIII (Fig. 7) (RIC I, p. 83, no. 519). ${ }^{12}$

at his time was in position to leave Armenia to Parthia and take all the necessary precaution to protect the borders. At the time, no vital interest of Rome was endangered, because Parthia indeed was no seriuos threat to Rome, not without a radical transformation of the state, which was unlikely. On the other hand, the abandoning of Armenia was a bad political move, because national dignity could not be easily broken. With smart diplomatic action in 20 B.C. Augustus succeeded in returning the earlier captured standards and survived captives. On this occassion, he was proclaimed an emperor for the ninth time and his diplomatic victory was celebrated as a victory won in the battle-field (CAH X: 255-256, 260-263; Sutherland 1987: 13-15).

9 Illustartion taken from Burns and Overbeck1987: 36, cat. 68 .

10 Illustration taken from BMC I, P1. 1.10.

11 Illustration taken from BMC I, P1. 16.17.

12 Illustration taken from BMC I, Pl. 2.4; Spannagel (Spannagel 2000: 622-629) studied the chronology of these as well as the Augustus' emissions signis receptis by following the appearance of legends, their changing from recepta to capta, as well as their shortening from capta to cap, and finally the disappearance of the legend next to the Mars Ultor temple, on which there is only an insignia 
In Augustus' mintings, we find a great number of different types with images of conquered nations, and so, next to the mintings dedicated to Parthia and Armenia, there are also other motives of defeated Germans. Celebrating victories of Tiberius and Drusus in Germany, in 12 B.C. Augustus minted coins with an image of a German kneeling and giving away a vexillum (Fig. 8) (RIC I: 74, no. 416). ${ }^{13}$ The German is depictied with long hair and beard, in a cloak and wearing trousers. This picture has its prototype in a kneeling Parthian from 18 B.C.

One more motive should be added to this group, on which Augustus himself was depicted. The victory of Tiberius in 7 B.C. in Germania, won under Augustus' auspiciae, resulted, among other thing, in surrendering the captives (BMC I: cxvi), which was illustrated on aurei and denarii with a scene in which a barbarian, dressed in a cloak, gives a child to Augustus, sitting on a platform (Fig. 9) (RIC I: 55, nos. 200-201). ${ }^{14}$ There is an opinion that this scene is ceremonial and stressing Augustus' mild rule, inspiring the barbarian to give him his child to protect. This would more correspond to Augustus' real policy towards the provinces and wishes after Tiberius' German triumph. The free will of the barbarian is depicted in his unforced gesture and upright position (Brilliant 1963: 76).

From the establishing of principate and the reign of Octavian Augustus, when civil wars, which lasted for decades, were over and the border of the Roman state was consolidated in wars with barbarians in the East and the West, there was a time of peace, without bigger military campaigns. This period lasted until the civil war in $68 / 69$, along with which there were mutinies in some provinces. The biggest problem was the re-

inside the temple.

13 Illustration taken from Burns and Overbeck1987: 36, kat. 69; The leginary eagle of the V legion was lost under the command of M. Lolius in 16 B.C, although there are no data that it was re-captured by the time of these mintings (CAH X: 360-363).

14 Illustration taken from BMC I, Pl. 12.13. bellion in Judaea, which lasted for four years and in which war operationswere conducted by Vespasianus and Titus. After great efforts, the Romans succeeded in conquering Jerusalem and finaly end the rebellion in the year 70. After that, the father and the son celebrated their triumph in Rome. This victory was much reflected in the mintings of Vespasianus and Titus, just as in pictures of defeated Jews in several similar composition schemes.

Along with the legend IVDAEA CAPTA, a palm-tree in the middle of the composition is depicted, a Jewish woman sitting on the ground and mourning, either left or right from the tree and a Jewish man standing with his hands tied behind his back, surrounded with captured weapons (Fig. 10-12) (RIC II: 68, nos. 424-426 (Vespasianus); RIC II: 86, no. 608 (Titus)). ${ }^{15}$ Along with these there are also motives with the emperor. Vespasianus is depicted as Virtus - he is a victor holding a parasonium and a spear, stepping on a helm and standing next to a palm-tree under which there is a Jewish woman sitting and mourning, with the legend IVDAEA CAPTA (Fig. 13) (RIC II: 68, no. 427).$^{16}$ Titus was depicted in a similar way, as a victor in Judaea and the conqueror of Jerusalem, standing in a military siut, with his foot on a bow of a ship, infront of him a Jewish man and a woman with their arms stretched in a begging gesture. Behind the captives there is a palm-tree (Fig. 14) (RIC II: 89, no. 638). ${ }^{17}$

Within indepenent mintings of Titus and especially Domitianus, the tradition of showing defeated uprising provinicies continues. On Titus' mintings from 79, minted after Agricola's success in Britannia, there is a trophy infront of which there is a caprive kneeling, with his hands tied behind his back (Fig. 15) (RIC II: 116, nos. 1-2). ${ }^{18}$ Later on, for several years, Domitianus minted coins celebrating his triumph over the Hattes in 83, which followed the examples of Vespasian's

15 Illustrations taken from BMC II, P1. 20.9, 20.7, 20.4.

16 Illustration taken from BMC II, Pl. 20.10.

17 Illustration taken from BMC II, P1. 26.2.

18 Illustration taken from BMC II, Pl. 8.2 
Ivdaea capta types. A central spot in these compositions is taken by a trophy (instead of the former palm-tree), next to which there is a German woman mourning and a Geman man standing with his hands tied, both surrounded with captured weapons, along with a legend GERMANIA CAPTA (Fig. 16) (RIC II: 186, no. 252; 189, no. 278; 194, no. 312 ; 197 , no. 341$).{ }^{19}$ On the same occasion of Domitianus ' triumph, he minted aurei and denars with a new reverse motive, on which there is a personification of Germania. A female figure, naked down to her waist, sits on a hexagonal shield mourning, and under the shield there is a broken spear (Fig. 17) (RIC II: 161-4, nos. 66a, $69,77,83,90 ; 167$, no. $111 ; 169$, no. $127 ; 173$, no. 164). ${ }^{20}$ Along with these, there are two other iconographical types with the picture of the emperor himself, both on the same occassion. On the first, there is Domitianus shown wearing a military suit, holding a parasonium and a spear, with his right fot stepping onto the lying personification of the Rhine (Fig. 18) (RIC II: 187, no. 259; 190 , no. 286 ; 194 , no. 319 ; 197 , no. 345 ; 199 , no. $362),{ }^{21}$ while in the second case, he is shown as a dignifying, gracefull victor, who accepts the pleas of a defeated German, who kneels infront of him, offering him a shield (Fig. 19) (RIC II: 187, no. 258; 190, no. 285 ; 194 , no. 318$).{ }^{22}$ The motive of a kneeling captive has its prototype in Augustus Parthian, although in this case the whole picture is dominated by a glorifying fugure of the emperor. The cennection of the heriozed source of victory with the conventional picture of a captive is an attempt to underline Domitianus as a figure. Even more, the psychological character is shown through the humble position of the German, who is focused watching the emperor, who, on the other hand, holds his right arm bent and placed over the chest, in his dignity, holds the right to

19 Illustration taken from BMC II, Pl. 70.8. 20 Illustration taken from BMC II, P1. 62.11. 21 Illustration taken from BMC II, Pl. 76.7. 22 Illustration taken from BMC II, Pl. 73.1. step aside from the direct involving in this historical event (Brilliant 1963: 97-98).

Trajan's military success can be followed on different reverse motives on coins, from the first and the second Dacian war to the campaign against the Parthians. The conquering of Dacia is still the greatest success during the reign of Trajan, won after two military campaigns. The coins with COS III within the legend are the only ones that can with certainty be connected to the first campaign, while those with COS V and COS VI point out to the second campaign or the war in the whole (RIC II: 238). According to that, among all of the pictures of captured Dacians, only one can be ascribed to the first campaign. A naked man is shown (Virtus Augusti ?) holding a trophy, under whom there is a naked Dacian lying, lifting his right hand in a begging gesture towards the main figure (Fig. 20) (RIC II: 249, no. 70). ${ }^{23}$ Although there are opinions that determined the naked male figure as an image of Trajan (Strack 1931: 107, ref. 419), ${ }^{24}$ we would rather agree with Matting$1 y^{6}$ s opinion, who considers that this figure can under no circumstances be Trajan depicted in his »heroic nakedness «, because the tradition of the early imperial art knows no such pictures of emperors. The closest analogy to this picture was an example of Galba, on which Virtus is also shown not as a warrior-goddess, but a naked warrior, i.e. the conception of manhood (BMC III: 1xix; RIC I: 233, no. 12).

All the other pictures of captured Dacians on Trajan's mintings are dated widely from 103 to 111 and can be brought in connection with the second Dacian war or the conquering of Dacia in general. On aurei and denars, there is a figure of a Dacian, with a traditional conical cap, dressed in a long-sleeved tunic and trousers, sitting on an oval shield in a mourning gesture, and under the shield there is a sica (Fig. 21) (RIC II, 250, no. 89,

23 Illustration taken from BMC III, P1. 11.11.

24 RIC II: 249 again identifies the naked figure with Trajan. 
258, nos. 216-219). ${ }^{25}$ This motive has Domitianus' Germania for its prototype. Along with this, there are also other pictures of captured Dacians, dressed like on the example mentioned, with the legend DAC CAP: a captive is sitting, hands tied behind his back, on a pile of weapons and military equipment (Fig. 22) (RIC II: 250, no. 96); ${ }^{26}$ sitting mourning on a pile of weapons, leaning his head on his arm (Fig. 23) (RIC II, 251, nos. 97-98); ${ }^{27}$ a captive standing, his hands tied on the front, around him there are shileds, sicae and a spear (Fig. 24) (RIC II, 251, no. 99); ${ }^{28}$ a Dacian, naked down to his waist, wearing trousers, hands tied behind his back, kneeling on a pile of weapons (Fig. 25) (RIC II: 288, no. 620). ${ }^{29}$ There are examples on which the legend DAC CAP was left out: a Dacian sittin mourning at the bottom of a trophy (RIC II, p. 251, nos. 220-221); sitting on a pile of weapons and military equipment, leaning his head on his hand, with a trophy infront of him (Fig. 26) (RIC II: 283, nos. 560-562); $;{ }^{30}$ a Dacian sitting on shileds and holding a trophy, infront of him there are hexagonal shields (RIC II, p. 284, no. 566).

In the official propaganda policy, Trajan declared himself as an optimus princeps, daring to use one of Jupiter's epithets, considering that he undoubtfully made contribution to bringing the state into the optimus status rerum..$^{31}$ Trajan, the powerful conqueror, who held the destiny of the world in his hands, showed good relationship with the senat on a picture on which he brings a kneeling Dacian and handed him over to one of

25 Illustration taken from BMC III, Pl. 11.20.

26 Illustration taken from BMC III, Pl. 15.14.

27 Illustration taken from BMC III, Pl. 15.15.

28 Illustration taken from BMC III, Pl. 15.13.

29 Illustration taken from BMC III, Pl. 35.9.

30 Illustration taken from BMC III, Pl. 28.7.

31 The legend on th coins S P Q R OPTIMO PRINCIPI is rather exceptional. After the first Dacian war, the senat brought a decision in which it expressed its respect, loyality and gratitude to Trajan for his virtues and success. On the coins it appears between 104 and 111. Dative shows that coins were not minted after emperor's orders, but in his honour and glory (BMC III: 1xx). the senators (Fig. 27) (RIC II: 258, no. 215). ${ }^{32}$ This represents an expression of Trajan's legalism in his relationship with the senat, according to the traditional right of making peace with foreign lands. Since the coins cannot precisely be dated, according to this, we can conclude that this scene is related to the end of the first Dacian war, since after the second war, Dacia no longer existed as a state. The next scene is surely connected to the end of the campaign and the final conquering of Dacia. Trajan is shown in his military suit, holding a spear, stepping with his foot on a Dacian, of whom only his head and his shoulders are visible (Fig. 28) (RIC II: 258, no. 210; 282, n. 547). ${ }^{33}$

The Parthian campaign from 115 to 117 found less expression in Trajan's mintings, but there are still aurei and denars with motives of captives and a legend PARTHIA CAPTA. Two captives are shown sitting at the bottom of a trophy, dressed in a kind of dress with long sleeves and trousers, leaning their heads on their hands and infront of each captive there is a bow and a quiver (Fig. 29) (RIC II, p. 267, nos. 324-325). ${ }^{34}$ After Dacia and Arabia, Trajan added two more provinces to the empire - Mesopothamia and Armenia. On the coins with the legend ARMENIA ET MESOPOTAMIA IN POTESTATEM P R REDACTAE Trajan is shown in supernatural size, as a heroic example of Virtus, with a spear and a parasonium, stepping onto two river-gods (Tigrus and Euphrates), and in the middle there is Armenia sitting and mourning (Fig. 30) (RIC II: 289, no. 642). ${ }^{35}$ The emperor is shown in great dignity with a parasonium, the amblem of Virtus ' authority, whose divine character he takes over.

During Hadrian's reign, there was an attempt to canonize pictures of provinces" personifications, but they belong to the group of fida et pacata provinces, which will be a matter of discussion in the next chapter. On some mintings of

32 Illustration taken from BMC III, Pl. 13.14.

33 Illustration taken from BMC III, Pl. 30.3.

34 Illustration taken from BMC III, P1. 20.6.

35 Illustration taken from BMC III, Pl. 42.8. 
Antoninus Pius Britannia is shown as a »pacified « province. The personification is shown sitting on a rock, leaning her head sadly on her hand, next to her there is an oval shield and aquila or vexillum (?) (Fig. 31) (RIC III: 142, nos. 930, 934). ${ }^{36}$ These coins were minted in $154 / 155$, on the occassion of successfull defeat of barbarians and the end of errecting the second wall, to the north from Hadrian's wall, for a better protection of the border. On the coins, saddness is pointed out in the gesture of the personification, which can be connected to the atmosphere brought by the barbarians from the north, since Britannia is shown armed and protecting the border (the wall) of the province (CAH XI: 337; RIC III: 11-12). Since already in Hadrian's times, and during Antoninus Pius, Britannia was already defined and depicted as a provincia fida, the ,pacified“" Britannia now represents a „,bordering" case between the capta and fida provinces. ${ }^{37}$ In the same manner, the personification of Africa is shown on a medallion after the successfull defeat of the rebellion in Mauretania. ${ }^{38}$ According to the motive shown, one can conclude that the problem was more complicated than the one in Britannia. The emperor is represented wearing a military suit with a spear, opposite of him lies Africa and in the middle of the picture there is Victoria, placing a shield on a trophy (Fig. 32) (Gnecchi II: 12, no. 25). ${ }^{39}$ The personification of Africa on this medallion reminds iconographically on Hadrian's Africa from his series provincia fida.$^{40}$ One cannot

36 Illustration taken from BMC IV, Pl. 48.14.

37 The personification is sitting mourning, but still partly armed and sitting on the wall - border towards the barbarians.

38 From Antoninus Pius and during the time of his heirs, ending with Commodus, one comes accross a greater number of captives on medallions. From 144 to150, the Bellum Mauricum took place (Kienast 2010: 134); The seriousness of clashes that took place there is best represented with the fact that the Legio VI Ferrata was sent from Judaea to help, as well as the cavalry units from Spain, Germania and Pannonia (CAH XI: 336-337).

39 Illustration taken from Gnechi II, Tav. 47.2

40 Africa from the series provincia fida of Antoninus Pius is in an upright position. conclude that the figure of the personification is especially sad and if there were no representations of the emperor, Victoria and the trophy, one could presume that it represents a picture of a provincia fida.

During the common reign of Marcus Aurelius and Lucius Verus, one comes accross pictures of captives again. The superior command in expeditio orientalis was given to Lucius Verus, while Marcus Aurelius stayed in Rome (CAH XI: 346). For both emperors, the same types of reverse motives were minted, with the personification of Armenia who sits mourning. Infront of her there is a shield and a standard, ande behind her there is a trophy, with the legend ARMEN (Fig. 33) (RIC III: 219-220, nos. 78-85; 222, nos. 121-122 (Marcus Aurelius); RIC III, p. 322, nos. 1364-1369 (Lucius Verus)). ${ }^{41}$ Apart from this scene, on the mintings of Lucius Verus there are also some other, similar pictures with the same legend. The differences include details surrounding the personification, who always sits mourning (RIC III: 254-255, nos. 498-509). On medallions, one comes across new motives. Lucius Verus is shown lifting a trophy, and next to his feet kneels the personification of Armenia in a begging gesture; the legend is ARMENIA (Fig. 34) (Gnecchi II: 45, no. 5). ${ }^{42}$ Next to Armenia there are also pictures of a captured Parthian who sits with his hands tied behind his back, next to his feet there are a bow, a quiver and other weapons (RIC III: 257, nos. 539-542, 258, nos. 547-548). There are also several variations of the personification who sits surrounded with weapons and the image of a trophy (Fig. 35) (RIC III: 326, nos. 1429-1435). ${ }^{43}$

41 Illustration taken from BMC IV, Pl. 76.7A; Matevosyan (Matevosyan 2000: 27-32), while studying state symbols of Armenia on Roman coinage, on one of these examples (BMC IV, Pl. 58.3), next to the personification of Armenia, who sits mourning, he recognizes the picture of an eagle on a bow. In such a way, he finds sources for the modern appearance of the Armenian emblem.

42 Illustration taken from Gnecchi II, Tav. 72.4.

43 Illustration taken from BMC IV, P1. 79.3. On coins of Marcus Aurelius there is a picture of three trophies, which 
During the single reign of Marcus Aurelius, he minted numerous examples marking victories in Germania, with similar motives and with the legends GERMANIA SVBACTA, GERMANICO or DE GERM: The personification of Germania sits at the bottom of a trophy, surrounded with different weapons (RIC III: 234, nos. 277-280; 235, nos. 289-291; 294-295, nos. 1021-1027); she sits surrounded with weapons, without a trophy (RIC III: 297, nos. 1053-1056; 300, nos. 1094-1095); in the middle there is a trophy, to the left there is a German woman sitting on two shields, to the right there is a German with his hands tied behind his back (Fig. 36) (RIC III: 297-298, nos. 1058-1068; 306, nos. 1179-1182); ${ }^{44}$ two captives sitting at the bottom of a trophy, with their hands tied (RIC III: 239, no. 339). The victory over the Sarmatians is especially pointed out and depicted with the same motives. Only the legend is different and it says DE SARM, appearing both on Marcus Aurelius' and Commodus' mintings, who was proclaimed augustus (Fig. 37) (RIC III: 239, no. 340; 240, nos. 341-342; 241, no. 364; 306-307, nos. 1185-1189 (Marcus Aurelius); RIC III: 339, n. $1571-1575$ (Commodus). ${ }^{45}$ On a sestertius from 171/172, Marcus Aurelius was depicted wearing a military suit, holding a spear and accepting a shield from a kneeling figure (?), most likely Germania. The legend is CLEMENTIA AVG and appears together with GERMANIA SVBACTA types, so that one can presume that one is dealing with the personification of Germania. With this legend, the emperor attempts to stress his mildness and mercy towards the defeated enemy (Fig. 38) (RIC III: 294, no. 1019). ${ }^{46}$ Marcus Aurelius also marks his victories in Germany with pictures on medallions with the legend GERMANIA SVBACTA. The emperor is depicted wearing a

should mark three victories won in the East: the Armenian, the Parthian and the Median one (RIC III: 288, no. 947).

44 Illustration taken from Burns and Overbeck1987: 54, cat. 120 .

45 Illustration taken from BMC IV, P1. 88.6. 46 Illustration taken from BMC IV, P1. 82.8. military suit, holding a spear and standing infront of a trophy. At its bottom, there are two captives sitting, while Victory on the other side places a shield onto the trophy (Fig. 39) (Gnecchi II: 27, no. 7). ${ }^{47}$ During the single reign od Commodus, only once, on a medallion, a picture of captives appears, who loose their national characteristics, resembling small figures at the bottom of a trophy. On the other hand, Commodus is shown wearing a military suit, with a spear, placing a trophy (Fig. 40) (Gnecchi II: 68, no. 153). ${ }^{48}$ Since there is no legend that would point out which one of the victories is depicted and since the medallion is dated into 183 , we can presume that is shows a military intervention at the border with Dacia, which began the year before (CAH XI: 379).

Septimius Severus illustrated his victory in the civil war against Pescenius Niger with the motives already known: a trophy and a captive sitting at its bottom (Fig. 41) (RIC IV.1: 97, no. 55; 98 , no. $63 ; 149$, nos. $432-434 ; 185$, no. 690$)^{49}$ or captives sitting on shields, with their hands tied (Fig. 42) (RIC IV.1: 98, no. 62), ${ }^{50}$ along with the legend PART ARAB PART ADIAB. ${ }^{51}$ After the clash with Albinus in the west, in 197 Severus returned to the east in order to solve the Parthian problem, which he had to postpone. A brief and successfull military operation was preformed and Ktesiphones was taken already by the end of October of the same year (Kienast 2010: 156). The legends PART MAX or PART MAXIMVS are written on pictures of trophies and captives, which are iconographically identical to the previous ones (RIC IV.1: 110, no. 153; 114, no. 176; 115 , no. $184 ; 158$, nos. $494-495 ; 161$, no. 512$).{ }^{52}$

47 Illustration taken from Gnecchi II, Tav. 59.9. 48 Illustration taken from Gnecchi II, Tav. 88.6. 49 Illustration taken from RIC IV.1, Pl. V.15. 50 Illustration taken from BMC V, Pl. 8.14.

51 The victory over Pescenius Niger was won at the beginning of 194, bringing to Septimius Severus in August 195 the titles parthicus arabicus and parthicus adiabenicus. In January 198, the parthicus maximus was added.

52 The same motive appears on Caracalla's mintings under Severus (RIC IV.1: 220, no. 55; 222, nos. 63-65. 
After the victory in Britannia in 210, Septimius Severus minted sestertii with a triumphal group, showing the emperor accompanied by his two sons and a soldier with the insigniae, while there is a tied captive sitting on the ground (Fig. 43) (RIC IV.1: 200, no. 799). ${ }^{53}$ The emperor, who is a victor, is placed between his heir-sons and the army, who won the victory, maybe just addressing the soldiers and recommending heirs to their loyalty. Comositionally similar to the previous one is also the scene on Geta's mints from the same year, on which there are only brothers depicted, accompanied by soldiers, with a captive sitting next to their feet (Fig. 44) (RIC IV.1: 335, no. 157; 337 , no. 157). ${ }^{54}$ It is noticeable that conceptive personifications of provinces, being previously summarized on pictures of captives with their national characteristics, slowly fade and now appear as parts of compositions with a different basic sense. Apart from victory, dynastic propaganda is also present, clearly recognizable on the picture of Caracalla on the coins from 198, when he was proclaimed an augstus. The young heir is depicted wearing a military suit with a spear, holding Victoria on the globe, while there is a captive sitting next to his feet, along with the legend IVVENTA IMPERII (Fig. 45) (RIC IV.1: 214, no. 20). ${ }^{55}$ The same picture is to be repeated by Caracalla in his independant minting after the war against the Parthians, with the legend VICT PARTHICA (RIC IV.1: 260, no. 315).

Up to the time of Galienus, one no longer cmes accross pictures of captives and trophies. During the reign of this emperor, they were used again on a big scale as propaganda on coins. On one hand, pictures of captives were summarized to an ordinary small figure sitting at the bottom of a trophy, with his hands tied and without any national characteristics, either as clothes or weapons and equipment. The only thing that points out to

53 Illustration taken from BMC V, Pl. 57.8.

54 Illustration taken from BMC V, Pl. 59.3.

55 Illustration taken from BMC V, Pl. 29.13. the national belonging of the captives is the legend and the whole composition should indicate victory. Two standardized combinations of pictures and legends appear on Gallienus' mintings: a trophy and two captives sitting at its bottom and the legend GERMANICVS MAXIMVS (Fig. 46) (RIC V.1: 70, no. 18) ${ }^{56}$ or Victoria (sometimes on the globe), who is stepping and holding a wreath, on both sides of her feet there is a captive, almost identical to the motive with the trophy and the legend VICT GERMANICA (Fig. 47) (RIC V.1: 72 , no. 49$).{ }^{57}$ The succeeding rulers, all the way to the end of the principate, minted similar motives with the same message. We shall show only some examples of motives with trophies and captives: Claudius Gothicus and Quintillus, with the legend VICTORIAE GOTHIC (Fig. 48) (RIC V.1: 223, no. $252 ; 247$, no. 87$) ;{ }^{58}$ Probus with the legend VICTORIA GERM (Fig. 49) (RIC V.2: 41, no. 222). ${ }^{59}$ The only new thing in depicting captives during this period is Aurelian's minting after his conquering of Palmyra in 272. Along with the legend ORIENS AVG there is Sol depicted in the middle of the cmposition with a globe in his hand, hile there are two captives, each one sitting either left or right of his feet (Fig. 50) (RIC V.1: 293, no. 252). ${ }^{60}$

56 Illustration taken from Burns and Overbeck 1987: 61, cat. 142. In Gallien's mintings, both pictures appear in a huge number and they will not be exceptionally named here.

57 Illustration taken from Burns and Overbeck 1987: 61 , cat. 143 .

58 Illustration taken from Burns and Overbeck 1987: 63, cat. 150 (Claudius Gothicus).

59 Illustration taken from Burns and Overbeck 1987: 64, cat. 155.

60 Illustration taken from Burns and Overbeck 1987: 44, cat. 92. Sol appearing on coins from 3rd century is not the Roman Sol, but solar divinity from Emesa, to whom Elagabalus showed utmost respect as Sol Invictus. In 274, Aurelianus errected a huge temple to Sol Invictus, the divinity which was identified with the Roman Sol (deus Soli Invictus). He built this temple from the gain he won during the war against Zenobia and it was believed that he won it with the help from Sol (OCD: 999; Stevenson 1964: 753755). 


\section{PROVINCIA FIDA ET PACATA}

The images of provinces went through phases from capta to fidem, which can also be recognized on coins. During the time of their conquering and durign the years when they were still rebelling, we see personifications of provinces through the images of captives, defeated oponents, sitting and mourning, tied and surrounded with captured weapons, begging for mercy. In time, newly founded provinces gradually become romanized and incorporated into the administrative, military and political life of the empire, they are depicted on coins like friends of Rome.

On Galba's mintings, for the first time, one comes accross images of provinces' personifications which are shown as friends of Rome and with their national characteristics. The real cause was showing gratitude to Gaul and Spain, which supported Galba during the civil war. ${ }^{61}$ Next to the legend GALLIA HISPANIA there are personifications of these two provinces in a dextrarum iunctio gesture. Gallia stands to the left, depicted with a female figure in a short tunic, holding a scepter with a boar on top, while Spai stands to the right, illustrated with a male figure of a warior wiht a shiled, parasonium and a spear (Fig. 51) (RIC I: 233, nos. 15-18). ${ }^{62}$ Special honour for Spain was given by Galba in the form of two pictures on coins, both with the same legend HISPANIA. ${ }^{63}$ On the first one, there is a pesonificized bust of Spain, with her hair tied from the forehead towards the neck, one curl falling down her neck, and behind the bust there are two spears, a round shield and below there are two ears of grain (Fig. 52) (RIC I: 232, nos. 1-3). ${ }^{64}$ On the second one, the personification of the province is shown as a whole figure, standing, dressed in a tunic, holding

61 In 68 there was a rebellion in Gaul and Spain against Nero, led by Vindex and Galba.

62 Illustration taken from BMC I, P1. 53.6.

63 During the rebellion against Nero, Galba was the governor of Tarraconic Spain.

64 Illustration taken from BMC I, P1. 53.1. grain ears and poppy in her right hand and a round shield and two spears i her left (Fig. 53) (RIC I: 233, nos. 19-21). ${ }^{65}$

During the first few years of his reign, Trajan minted several denars and aurei with a picture of a female figure, the personification of Germania. She was shown sitting on two hexagonal shileds, between which there is a helm, naked down to her waist, with her hair tied in a long braid, holding a branch in her right hand (Fig. 54) (RIC II: 245 , no. 5 ; 246 , no. $15 ; 247$, no. 35$) .{ }^{66} \mathrm{Al}-$ though the legend does not say it precisely, according to the hair style and the shape of the shields, one is undoubtfully dealing with Germania. It represents the first image of a province that was fida et pacata, in the real sense of the word and in such a manner appeared on Roman coins. Trajan commanded the troops in Upper Germania before he was adopted by Nerva and it is therefore logic that in such a manner, at the beginning of his reign, he confirmed the existing relationships in Germania.

In 106, Arabia became a Roman province in a peaceful manner, and therefore it was defined on coins with the legend ARAB ADQVIS. It is represented as a female figure, holding a branch in her right hand, and in her left a bundle of cinnamon or calamus (?), next to her feet there is a camel (Fig. 55) (RIC II: 250, nos. 94-95; 261, nos. $244-245 ; 278$, nos. $465-468 ; 287$, nos. $610-615){ }^{67}$ The personification is shown with the attributes of her country - cinnamon or calamus (?) and a camel, while she holds a branch in order to stress her character as pacifera. ${ }^{68}$

65 Illustration taken from BMC I, P1. 53.8.

66 Illustration taken from BMC III, P1. 9.5.

67 Illustration taken from BMC III, Pl. 33.4.

68 From the very beginning of systematic cataloguing of Roma imperial coins in 19th century up to the present day, the authors did not succeed in certain determining of the object held by the personification of Arabia in her left hand. Naster (Naster 1983: 159-169) was dealt with this problem and named all of the opinions so far (Cohen, RIC, Strack, BMC, Mazzini, Robertson, Beloni, Kent, Carson, Toynbee, even considering ancient sources) about that. He accepts Toynbee's opinion, who thinks that it is a calamis odorata, i.e. calamus (a herb with aromatic leaves). 
Up to 112, Dacia was shown as provncia capta on Trajan's coins, but in that year it became a provincia pacata. From that year onwards, it was marked on coins as DACIA AVGVST PROVINCIA and shown with a personification who is sitting on a rock, wearing a conical cap, holding a legionary eagle and next to her there are two children holding grapes and grain ears (Fig. 56) (RIC II: 288, nos. 621-623). ${ }^{69}$ According to Trajan, Dacia was a pacified province ever since, but it still needs Roman weapons (aquila) to defend itself, and within such an attitude there is a room for it to make progress in peace. The image of Dacia as a pacata province appears on coins exactly at the moment when the East takes over the central position in Roman affairs, most likely representig a political move of Trajan, because it was far from being pacified. After all, it will be shown by its representation in Hadrian's series, on which it does not carry any signs of welfare, but a legionary eagle.

The first and the only attempt to canonize provinces' personifications appeared on several independent series of Hadrian's minting: the „province“, ADVENTVS and RESTITVTOR types. ${ }^{70}$ In the ,provinces“" series, eleven provinces, Italy and Alexandria were depicted. The provinces include Africa, Egypt, Asia, Britannia, Capadocia, Dacia, Germania, Spain, Judaea, Mauretania and Sicily. It remains partly unclear why exactly these provinces were chosen and not some others. This especially goes for Syria, where Hadrian had supreme military command at the time of Trajan's death and was chosen for an emperor exactly by these legions. Syria, or better Syrian army, apears only on the EXERCITVS series, on which more attention was given to it than to any other army in any of the provinces. Apart from that, it can be noticed that Alexandria was

69 Illustration taken from BMC III, P1. 37.10. 70 Apart from these, there is also an EXERCITVS series, which names armies from ten provinces and praetorians. But here, we come across a classical adlocutio picture, and not with pictures of provinces' personifications. again especially honoured with an independent picture, as well as in theadventus series. Looking for an answer to the first question, Strack concluded that some of the provinces were unimportant (Sardinia, Corsica, Epirus etc.), others were within the frames of some of the named provinces (Cyrenaica under Libya, Galatia under Cappadocia, Pamphylia and Lycia under Cilicia), while Pannonian provinces were reserved for L. Aelius (Strack 1933: 145). Mattingly considers that it is wiser to admit that we cannot be certain about the reasons for any of these examples, but he agrees that Pannonian provinces were reserved for Aelius (BMC III: clxxiv, clxxv). Hadrian“s ,provinces" do not completely correspond to the Roman admnistrative division and some of them include a group of provinces. They no longer represent a mixture of administrative regions and certain nations or broader regions. Pictures of provinces personifications and nations are depicted in two conceptions: like pacata and like vigil. Mattingly makes his division in forms of pictures in which he also includes the one given by Strack, with certain compression, so according to him, we get the following picture: a) provinces' personifications shown as divinities and half-divinities (Strack's types 1,2$)$; b) province's personifications shown as war divinities (Strack's type 3) and c) these that are shown with their national attributes and costumes (Strack's types 4, 5). Since it is difficult to make such a division between the groups b) and c) since a personification depictedas a war divinity can carry a certain local attribute, Mattingly, at the end concludes, that it is better to divide them into „peaceful“ and „militant“ (BMC III: clxxvii; Strack 1933: 153).

Egypt is depicted with a lying personification, leaning her elbow on a basket with fruits, while infront of her there is an ibis on a low pillar (Fig. 57) (RIC II: 374, nos. 296-297; 445, nos. 838-839). ${ }^{71}$ Africa also lies, with elephant-

71 With the legend AEGYPTOS. Illustration taken from BMC III, P1. 94.4. 
skin headdress, holding a scorpio and a cornucopia, while infront of her there is a basket with grain ears (Fig. 58) (RIC II: 374, nos. 298-299; 446, nos. 840-842). ${ }^{72}$ Asia stands, her right foot lies on a a bow of a ship, she holds a hook and a stern (Fig. 59) (RIC II: 374, no. 301). ${ }^{73}$ Britannia sits on rocks (most likely representing Hadrian's wall), leaning her head on her right arm and in her left, leaning on a big shield, she holds a spear (Fig. 60) (RIC II: 447, nos. 845-846).$^{74}$ Capadocia stands, wearing a corona muralis on her head, dressed in a short tunic, wearing a fur cloak and hunting boots, holding a model of Mons Argaeus and a vexillum (Fig. 61) (RIC II: 447, nos. 847848). ${ }^{75}$ Dacia sits on a rock, dressed in a tunic and a cloak, holding a legionary eagle and a sica (Fig. 62) (RIC II: 447, nos. 849-850). ${ }^{76}$ Germania stands, dressed in a long tunic, holding a spear and leaning her other arm on a shield (Fig. 63) (RIC II: 347-375, nos. 302-304). ${ }^{77}$ Spain sits leaning on a rock and holding a branch, next to her there is a rabbit (Fig. 64) (RIC II: 375, nos. 305-306; 448, nos. 851-852) ${ }^{78}$ The personification of Judaea stands in a long tunic, bringing sacrifice from a patera to the altar next to which there is a bull, behind her there is a child standing and infront of her there are two children holding palm-branches opposite of Hadrian, who stands dressed in a toga with his right hand lifted (Fig. 65) (RIC II: 448, no. 853). ${ }^{79}$ The treatment of Judaea in this series is unique, because it includes emperor's image

72 With the legend AFRICA. Illustration taken from BMC III, P1. 94.1.

73 With the legend ASIA. Illustration taken from BMC III, P1. 63.6.

74 With the legend BRITANNIA. Illustration taken from BMC III, Pl. 94.2.

75 With the legend CAPPADOCIA. Illustration taken from BMC III, Pl. 94.3.

76 With the legend DACIA. Illustration taken from BMC III, Pl. 94.12.

77 With the legend GERMANIA. Illustration taken from BMC III, P1. 63.8.

78 With the legend HISPANIA. Illustration taken from BMC III, Pl. 95.1.

79 With the legend IVDAEA. Illustration taken from BMC III, Pl. 95.3. within the composition. Instead of local attributes, the personification of Judaea is depicted as a new Roman, Hadrain's creation, bringing sacrifice infront of the emperor, while children represent a new generation, growing under the new regime. The personification which is shown followed by children would be an allusion for a new Judaea, with its growing population, supported by Hadrian in his new Jerusalem, the colony Aelia capitolina (BMC III: clxxix-clxxx). ${ }^{80}$ The images of Mauretania are twofold: first, dressed in a short tunic, walking and leading a horse on a string, her head turned back towards the horse and holding a spear in her other hand (Fig. 66) (RIC II: 448, nos. 854-856). ${ }^{81}$ Apart from that, she is also shown standing infront of a horse and holding the reins, dressed in a short tunic, while in her other hand there are two spears (Fig. 67) (RIC II: 449, nos. 858-860). ${ }^{82}$ Sicily is depicted with Medusa's head and a triscys behind it (Fig. 68) (RIC II: 450, no. 871). ${ }^{83}$ The personification of Pannonia minted under L. Aelius should be added to Hadrian's examples named above. It is shown standing, wearing a corona muralis on her head, holding the creases of her dress with her left hand, while in her right she is holding a vexillum, indicating cavalry (Fig. 69) (RIC II: 481, nos. 1059-1060; 482, nos. 1071-1073) ${ }^{84}$

Apart from the provinces named above, in this series there are also personifications of Italy and Alexandria. Italy holds a scepter and a cornucopia (Fig. 70) (RIC II, p. 375, no. 307) ) $^{85}$ and, opposite to other provinces, does not represent a personification with local characteristics,

80 Judaea is the only province in which Hadrian had major problems during his reign.

81 In both cases with the legend MAVRETANIA. Illustration taken from BMC III, Pl. 95.2.

82 Illustration taken from BMC III, P1. 95.6.

83 With the legend SICILIA. Illustration taken from BMC III, P1. 95.16.

84 With the legend PANNONIA. Illustration taken from BMC III, Pl. 95.2.

85 With the legend ITALIA. Illustration taken from BMC III, P1. 63.14. 
but bears ideological meaning. ${ }^{86}$ The personification of Alexandria lies, leaning on a basket with fruits, behind her there is a vine branch, holding grain ears in her hand, while infront of her there is wheat growing (Fig. 71) (RIC II: 446, nos. 843844). ${ }^{87}$ Alexandria obviously enjoys special privileges and that is why it is also shown in the adventus series. The accent on natural wealths is more expressed here than on the pictures of Egypt itself.

Although separated as a special series with provinces, we cannot neglect the images from the ADVENTVS and RESTITVTOR series, since on them, some other provinces also appear. ${ }^{88}$ Cappadocia, Dacia and Germania appear only in the „province“ series. The personifications of Africa, Asia, Spain, Sicily and Italy are the oly ones represented in all of the three series. The provinces" attributes are the same as in the ,provinces" series, except that in the case of Sicily grain ears also appears. Only the attributes of Asia differ, since on the second two series, it wears a corona muralis on its head and holds a scepter. Britannia, Judaea and Mauretania also appear in the adventus series. Britannia is shown without attributes; Judaea is with children again, while Mauretania shows a vexillum instead of a horse.

This would describe all of the personifications included in the "provinces" series, while others can be traced down according to their representations on other two series. Five provinces are represented both in adventus and restitutor series: Arabia, Bithynia, Gaul, Macedonia and Phrygia. Arabia is shown with the same attributes as earlies with Trajan, with a camel and a calamus (?) (Fig. 72); ${ }^{89}$ Bithynia holds an acrostolium, while her

86 The prosperity of provinces from the beginning of 2 nd century lead to a gradual decline of Italy's influence in all spheres, including the political one, which will especially be noticeable dring 3rd century (Méthy 1995: 25-49).

87 With the legend ALEXANDRIA. Illustration taken from BMC III, Pl. 94.6.

88 Adventus series (RIC II: 376, nos. 315-320; 451-456, nos. 872-907). Restitutor series (RIC II: 377-378, nos. 321-329; 463-467; nos. 938-966).

89 Illustrations (Fig. 72-77) taken from BMC III, P1. 96.4, foot lies on a bow of a ship (Fig. 73); Gaul is represented without attributes; Macedonia is dressed in a short tunic and holds a whip (Fig. 74); Phrygia wears a national cap and holds a curved shepherd's stick in her hand (Fig. 75). Cilicia, Moesia, Noricum and Thrace appear only in the adventus series, while Achaia, Libya and Nicomedia appear only in the restitutor series. Cilicia is shown with a helmet on her head, holding a vexillum in her hand; Moesia is dressed in a short tunic, holding a bow (?) and a quiver with arrows; Noricum, as well as Cilicia, wears a helmet and holds a vexillum; Thrace is shown dressed in a short tunic, without attributes; Achaia has an amphora with a palm-branch as the only attribute (Fig. 76); Libya is without attributes; Nicomedia, as the capital of Bithynia, just like Alexandria, enjoys special privileges appearing among the provinces. It is shown with a corona murales on its head and holding a stern (Fig. 77). The personifications of Asia, Bithiny and Nicomedia carry the same attributes connected to sailing, which can easily be understood regarding the importance of maritime routes through Hellespont.

The new understanding of a state's conception, promoted by Hadrian, was no longer based on the priority of Italy as mastress of the provinces, but in a partnership of all of the provinces for the well-being of the whole Empire. The idea he tried to explain and transform into reality depended much on his unique personality and cosmopolitan spirit. After Hadrian's death, Antoninus Pius also minted a ,provinces“" series, wishing to promote his attitudes taken in inner affairs, i.e. return to the traditional understandning of the relationship between Italy and the provinces. His series bears a completely different sense that the Hadrian's one, because we see provinces here hurrying to give offerings in the form of aurum coronarium. Italy, who is to receive all og the gifts, is depicted as the queen of the earth, sitting on a stary globe, holding a cornucopia and a spepter (Fig. 78) (RIC

96.6, 97.3, 97.4, 96.1, 97.1. 
III: 106 , no. 594 ; 122 , nos. $746-747) .{ }^{90}$ Africa is dressed in long clothes, with elephant-skin headdress, standing and holding a crown and a cornucopia or grain ears, a cornucopia and a basket (Fig. 79) (RIC III: 104, no. 574). ${ }^{91}$ Asia holds an anchor, next to her feet there is a bow of a ship (Fig. 80) (RIC III: 105, no. 579). ${ }^{92}$ Capadocia is in a short tunic, holding a vexillum, next to her feet there is Mons Argaeus (Fig. 81) (RIC III: 105, no. 580). ${ }^{93}$ Dacia, dressed in a short tunic, holds a standard (Fig. 82) (RIC III: 105, no. 581). ${ }^{94}$ Spain is in long clothes, holding a branch, next to her feet there is a rabbit (Fig. 83) (RIC III: 105, no. 582) ${ }^{95}$ Mauretania is in a military suit, holding a spear or a vexillum (Fig. 84) (RIC III: 105, nos. 583585 ; 122, no. 748) ${ }^{96}$ Parthia appears as a friendly kingdom, shown holding a bow and a quiver with arrows next to her feet (Fig. 85) (RIC III: 105, no. 586). ${ }^{97}$ Phoenicia holds a short scepter, next to her there is a bow of a ship and a palm-tree (Fig. 86) (RIC III: 106, no. 587). ${ }^{98}$ Scythia, in a short tunic, holds a parasonium (Fig. 87) (RIC III: 106, no. 588). ${ }^{99}$ Sicily wears a trisces on her head and long clothes, she holds poppy (Fig. 88) (RIC III: 106, no. 589). ${ }^{100}$ Syria holds a cornucopia, next to her feet there is a personification of Orontes (Fig. 89) (RIC III: 106, no. 590). ${ }^{101}$ Thrace holds a branch (RIC III: 106, no. 591). The only different picture is the one of Bithynia, because she is not offering the crown, but sits on a rock/wall, leaning on a shield and holding a military insignuim

90 Illustration taken from BMC IV, P1. 39.11. 91 Illustration taken from BMC IV, Pl. 26.4. All of the personifications hold a aurum coronarium in their right hand and it would not be repeated in the description, unless different.

92 Illustration taken from BMC IV, P1. 26.9. 93 Illustration taken from BMC IV, Pl. 26.10. 94 Illustration taken from BMC IV, P1. 26.12. 95 Illustration taken from BMC IV, P1. 26.13. 96 Illustration taken from BMC IV, P1. 26.6. 97 Illustration taken from BMC IV, P1. 27.1. 98 Illustration taken from BMC IV, P1. 27.4. 99 Illustration taken from BMC IV, P1. 27.2. 100 Illustration taken from BMC IV, P1. 27.5. 101 Illustration taken from BMC IV, P1. 27.6. and a spear (Fig. 90) (RIC III: 121, no. 742). ${ }^{102}$ Just like during Hadrian's times, the picture of Alexandria is especially separated. The personification, with a lotus flower on her head, holds the crown with both hands, next to her feet there are grain ears and a crocodile (Fig. 91) (RIC III: 104, nos. 577-578). ${ }^{103}$ Contrary to Hadrian's, the treatment of subjects under Antoninus Pius is depicted in a completely different spirit. Hadrian travelled throughout the empire and understood Italy and the provinces in the whole of their expanse and variety, as a unique political body, without stressing differences and privileges. Under Antoninus Pius, the provinces are depicted as loyal, but Italy still takes its privileged place (Strack 1937: 39).

In Commodus' mintings, a motive from the time of Antoninus Pius repeats, with a picture of Italy as the mistress of the world, sitting on the globe, holding a sceptre and a cornucopia (RIC III: 416, no. 438). The victory in Britannia in 184 finds its reflection on a medallion minted a year later, illustrating her as a provincia fida, sitting on a rock/wall, leaning her elbow on a shiled and holding a standard and a spear (Fig. 92) (Gnecchi II: 51, no. 2) ${ }^{104}$ On coins of Septimius Severus, on two occassions there are personifications of Africa. The first one is in 194, on sestertii with the legend AFRICA, there is Africa depicted as a standing female figure, with elephant-skin headdress, holding folds of her dress with her left hand, in which she also holds grain ears, next to her feet there is a lion (Fig. 93) (RIC IV.1: 183, no. 668; 184, nos. 676, 680). ${ }^{105}$ This picture appears during the war with Niger, on one hand wishing to show the important role of the province in supplying Rome with wheat. On the other hand, as it appears together with the image of di auspices, it certainly stresses the African origin of the emperor. ${ }^{106}$ The

102 Illustration taken from BMC IV, P1. 39.9.

103 Illustration taken from BMC IV, P1. 26.5.

104 Illustration taken from Gnecchi II, Tav. 78.2.

105 Illustration taken from BMC V, Pl. 22.6.

106 It is probably no coincidence that in the same year, in the mintings of Clodius Albinus there is an image indicat- 
second occasion is on denars dated in 207 and between 202-210, with the identical picture of Africa (RIC IV.1: 118, nos. 207, 207A; 123, no. 253) or a variant on which the personifiction reclining on a cornucopia, holding a scorpion and infront of her there is a basket with fruits (Fig. 94) (RIC IV.1: 123 , no. 254).$^{107}$ The latest reminds a lot of the Africa from Hadrian's "provinces" series and it was most likely minted on the occassion of the visit of emperor's family to their native country Africa in 202-203.

After that, we come accross pictures of provinces only on the mintings of Trajan Decius and these were of Pannonia and Dacia. Pannonia is depicted in two manners, as one or two figures, but in both cases, the legend says PANNONIAE. The personification is depicted in long clothes, standing, with her right hand lifted and holding a military insignia (Fig. 95) (RIC IV.3: 120, no. 5). ${ }^{108}$ As two figures, they appear in several varinats: personifications standing under a veil, both with their hands lifted, each holding a standard (Fig. 96) (RIC IV.3: 122, nos. 21-25). ${ }^{109}$ The Panonnias are depicted in a dextrarum iunctio gesture infornt of a standard, expressing mutual military loyalty (Fig. 97) (RIC IV.3: 123, no. 26; 124, no. 41). ${ }^{110}$ Dacai is represented holding a stick with a donkey's head on top (Fig. 98) (RIC IV.3: 120, no. 2; 121, no. $12 ; 124$, no. 35 . $)^{111}$ or holding a standard with the legend DACIA or DACIA FELIX (Fig. 99) (RIC IV.3: 121-122, nos. 13-14; 124, nos. 36-37). ${ }^{112}$

ing his African origin and his place of birth - Hadrumentum. On his aurei, Albinus depicts an African deity called saeculum frugiferum in Latin (RIC IV.1: 45, nos. 8-10). The deity is depicted on a throne with grain ears in his hands, flanked with two sphinxes. The picture undoubtfully reminds on a Punic relief from $5^{\text {th }}$ century B.C. from a sanctuary in Hadrumetum (Birley 2002: 112).

107 Illustration taken from BMC V, Pl. 34.18.

108 Illustration taken from RIC IV.3, Pl. 10.7.

109 Illustration taken from HCC III, Pl. 76.15. Variations: just one holding a standard or one standard between the figures.

110 Illustration taken from HCC III, Pl. 76.24.

111 Illustration taken from HCC III, P1. 75.7.

112 Illustration taken from HCC III, Pl. 76.21.
In the first place, Trajan Decius asked for support of the Illyrian army, which he often illustrated on coins with the legend GENIVS EXERCITVS ILLVRICIANI (RIC IV.3: 120, nos. $3-4 ; 122$, nos. $15-25 ; 124$, nos. 38-40). The appearance of the perosnification of Dacia is connected to the victory won against the barbarians on the province's border, after which Decius got the title Dacicus Maximus (Kienast 2010: 205). ${ }^{113}$ The special exposure of Pannonias as images on coinage in probably connected to Decius' place of birth in the vicinity of Sirmium.

For the last time during the proncipate, on Aurelian's mintings one comes across images of provinces" personifications. The accent is again given to the same group of provinces, and the following provinces are depicted on coins: Pannonias, Dacia and the Genius of Illyricum. The personification of Pannonia stands with her right arm lifted, in her left she holds a sceptre with the legend PANNONIAE (Fig. 100) (RIC V.1: 278, no. 113). ${ }^{114}$ In the case of Dacia, the motive from Trajan Decius' coins repeats, with the personification who holds a stick with donkey's head on top, with the legend DACIA FELIX (RIC V.1: 277, no. 108). The appearance of Pannonia is again probably connected to certain private reasons and the birth place of Aurelianus in the vicinity of Sirmium. Still, the images of Dacia and Genius Illyricum (RIC V.1: 277, no.110; 278, no. 111; 287, nos. 204-205; 189, nos. 222-224) are rather connected to the re-organisation of the Danubian border and the abandoning of Trajan's Dacia. ${ }^{115}$ Even more so because Aurelianus does not expose only

113 About the question of different depictions of Dacia on imperial and provincial mintings of Trajan Decius cf. Jovanović 2006: 41, I-2.

114 Illustration taken from RIC V.1, Pl. VIII.122.

115 The abandoning of Dacia and the evacuation of people most likely followed in several phases from 271-274. Aurelianus established a new province on the right Danube bank, which included parts of Lower Moesia and Thrace (CAH XII: 301, ref. 1). About the analysis of the development of Dacia's images on imperial and provincial coinage from Trajan to Aurelianus, cf. Winkler 1965: 225-233. 
the army of Illyricum like Trajan Decius before him, but just Illyricum itself.

Money as a source holds aspects of persons and time, and in most cases, it is placed within a real historical context. Images on Roman imperial coinage offer data about real events, depiciting them, of course, in the way that was the most acceptable for the administration. Emperors made a high level of political propaganda using coinage as the most powerful mean. Apart from coins, the succesfully used other means, like: public monuments, buildings and inscriptions, relief, miniature plastic, gems and cameos etc. Considering public monuments, the level of political propaganda was put down on the level of local population. This is why we come accross many public monuments and inscriptions throughout the Empire. In the case of miniature plastic, relief depictions on vessels or gems and camoes, the role of propaganda is pot down on the user's level. Money, on the contrary, was lifted above all other means, mostly because of its role as a mean of payment, which made it inevitable in everyday life and required its huge quantity. That circumstance was very well used from the very beginning of minting, firstly to outline belonging to a certain community and secondly also to spread propaganda ideas. As a skill, it develops through time, reaching its peak during the Roman empire. Minting of coins had its central role in Roman politics, as well as in the commercial life of the Empire (Harl 1996: 27).

Among others, pictures on coins offer data about numerous captured territories which were added to the Empire as provinces, about occupied nations, defeated enemies begging for mercy, about captured weapons and trophies, about emperors who are invincible but sometimes show mercy to captives. The coin series with the motive provincia capta show defeated nations or occupied countries which were turned into Roman provinces, usually personificized as captives carrying local features like clothes or weapons. On the other hand, the images of provinces' personi- fications as fida et pacata should point out to the pacified provinces, whose autochtonous population has been romanized and incorporated into the state system. Rome, which under Augustus rose onto the level of a world's empire, caused an artistic creation of a new conception of the archetype of enemies. Rome was no longer considered one of the sides in a bipartial world, as one side of culture, right and religion, opposed to the barbarian world. Instead of that, Rome was now placed between two extreme poles - on one hand, these are the northern and western barbarians, and on the other these are the representatives of old oriental civilisations, who respect their cultural attributes. Gauls and Germans as stereotypes were considered raw and uncivilized, but daring and reliable warriors, and as such valuable to the Romans. The orientals, on the other hand, were softened in luxury, they respect their cultural attributes and represent old civilizations (Hölscher 2003: 10). Already on Augustus' mintings we can see the differencies in depicting a Parthian and an Armenian, opposed to a German. A kneeling German is depicted with long, mussed up hair, and bearded, which would, according to Roman standards, correspond to an uncivilized and wild nation. Orientals are depicted in their national costumes, but in a dignifying manner, acceptable to the Romans.

The political propaganda of Augustus and his heirs all the way to Domitianus, did not depict the personification of Germania as a female figure and it was focused on depicting captives. On the other hand, it would be logical to expect a mourning personification of Germania to appear on Augustus' mintings, after historical events and the victory of Tiberius. But since she did not appear, it is to be concluded that during that period, such a way of depicting did not play any role (Künzl 1988: 545-546). Generally, Augustus' politics towards the defeated provinces was to cautious and conservative. Even more, the results of such a policy were present for a long time even after his death, which in a certain way set fatal borders 
to the possibilities of the Empire. The inevitable equalization of provinces with Rome and Italy was delayed until it was too late (Mattingly 1960: 151).

Vespasianus' propaganda on coins developed as a result of specific circumstances, grew out of the civil war and his personal promotion without adoption. The most important success was pacifying the rebellion in Judaea, marked with numerous motives on coins of Vespasianus and Titus, among others also with pictures of captives. A motive of a man and a woman is introduced, Jews, tied and mourning, surrounded with captured weapons. In the centre of the compostition there is a palm-tree, which in future mintings is to be replaced with a trophy, just like on Domitianus' Germania capta motive. This motive will develop through 2 nd and 3rd century into a stereotype picture of two captives sitting on the foot of a trophy with their hands tied. In Domitianus' mintings, a new motive appears of the personification of Germania sitting on a shield, which will later also be accepted, first by Trajan in his depictions of Dacia, but later also by Lucius Verus and Marcus Aurelius. The mentioned picture of Germania as a female figure, sitting on a shield on Domitianus' mintings, represents the first attempt of allegoric depiction of a province's personification. All of the former depictions of provinces“ personifications could be named ,captives", representatives of a certain nation, dressed in authentical costumes and with attributes typical for a certain country or county, so that they can well be treated as geographical personifications.

During $1^{\text {st }}$ century, provinces hardly appear on coins and they are almost always depicted as captives, with the exception of Galba's Spain and Gaul and Trajan's Germania. Galba's election for an emperor in Spain and their union with the rebellions in Gaul causes the emphasizing of these two provinces which appear as war-goddesses. But these images of Spain and Gaul are no results of Rome's care fot provinces, but the indication of provinces' unsatisfaction with central government, which caused the rebellion itself (Sutherland 1951: 175). For the first time on Trajan's mintings, the picture of a pacified province appears, in this case Germania, who symbolically holds a branch in her hand. The clothes corrspond to the simplified variant of a German national costume, so even when the explaining legend is missing, there is no doubt that it is Germania depicted.

After a plentitude of types depicting Dacia as broken and defeated, Trajan depicts this province as a new member of the Empire. As fida et pacata he illustrated his new province, Arabia. Only during the time of Hadrian were the provinces treated with respect and shown as such on his mintings. But Hadrian was an isolated visionary, whose ideas about functioning of the Empire were not approved by his heirs. Hadrian was the first emperor who gave special attention and a proper manner for treating the inner organization of the state in all of its segments. Still, it showed great connection to his original personality and character - Hadrian's provincial origin, natural curiosity and visionary gave him a broad view of things and strenght to persist in his ideas. His attitudes were perpetuated in his magnificent series ,provinces“, adventus and restitutor, which represent the climax of his life work, after that he has spent almost his entire rule visiting provinces and considering their problems on sight.

He understood the Empire as a living organism, equally consisting of all of its parts. But, as it was already pointed out, his heir showed no undertsanding for these progressive ideas. Antoninus Pius was in Italy with all of his heart and he lacked understanding, even with his noble character, for the true need of the state. His series „provinces“ shows them again in an obediant relationship towards Italy, who is the mistress of the world, sitting on a stary globe and who is being offered crowns. All of the later pictures of provinces" personifications was reduced to the images of captives and was aiming to advertise victory. 
On none of the pictures do captives bear national characteristics like clothes or weapons, they look alike on all of the images (Méthy 1992: 274). The only exception are certain mintings of Trajan Decius and Aurelianus, on which Dacia, both of Pannonias and the Genius of the Illyrian army apper, connected with short-term raise of the Balkan provinces and the local origin of the emperors. Basically, the pictures of provinces' personifications show a conception built by actual emperors about the Roman world and they represent visual testimonies of the contemporary Roman vision of the world.

\section{BIBLIOGRAPHY}

\section{Абрамзон, М. Г. 1995}

Монеты как средство пропафанды официальной политики римской империи, Москва: Российская Академия Наук, Институт Археологии.

Birley, A. R. 2002

Septimius Severus, The African Emperor, London and New York: Routledge.

BMC I-V. 1923-1950

Coins of the Roman Empire in the British Museum, London: British Museum Trustees.

\section{Brilliant, R. 1963}

Gesture and Rank in Roman Art, Memoirs of the Connecticut Academy of Arts \& Sciences, Vol. XIV, New Haven Connecticut: Connecticut Academy of Arts \& Sciences.

\section{Burns, T. S. and Overbeck B. H. 1987}

Rome and the Germans as seen in Coinage, Cata$\log$ for the Exhibition, München: Staaliche Münzsammlung München.

\section{CAH X-XII. 1971-1976}

The Cambridge Ancient History, Cambridge: University Press.

\section{Gnecchi, F. 1912}

I Medaglioni Romani, Vol. II, Bronzo, Bologna: Forni Editore.

\section{Grant, M. 1958}

Roman History from Coins: some uses of the imperial coinage to the historian, Cambridge: University Press.

\section{Harl, K. W. 1996}

Roman Economy 300 B.C. to A.D. 700, Baltimore (Maryland) \& London: The Johns Hopkins University Press.

\section{Hölscher, T. 2003}

Images of War in Greece and Rome: Between Military Practice, Public Memory and Cultural Symbolism, The Journal of Roman Studies, Vol. XCIII (2003): 1-17.

Kienast, D. 2010

Römische Kaisertabelle, 4. Auflage, Darmstadt: WBG.

\section{Künzl, E. 1988}

Die römische Personifikation der Germania, Kaiser Augustus und die verlorene Republik, eine Ausstellung im Martin-Gropius-Bau, 7. 6. - 14. 8. 1988 (Berlin), Mainz am Rhein: P. von Zabern, 545-546.

\section{Matevosyan, R. 2000}

Armenian state symbols on Roman coins, Cahiers Numismatiques, Bulletin de la Société d'Études Numismatiques et Archéologiques 37/145 (2000): 27-32. 
Mattingly, H. 1960

Roman Coins from the earliest times to the fall of the Western Empire, 2nd ed. revised and reset, London: Methuen \& Co.

\section{Méthy, N. 1992}

La représentation des provinces dans le monnayage Romain de l'époque imperiale (70-235 aprés J.C.), Numismatica e Antichità Classiche XXI (1992): 267-296.

\section{Méthy, N. 1995}

La représentation de l'Italie dans le monnayage romain de l'époque impériale, Revue Numismatique, 6e série, Tome 150 (1995): 25-49.

\section{Naster, P. 1983}

ARABIAADQVISTA sur les monnaies de Trajan, Numismatica e Antichità Classiche, XII (1983): 159-169.

\section{OCD. 1979}

The Oxford Classical Dictionary, Ed. by N. G. L. Hammond and H. H. Scullard, Oxford: Clarendon Press.

\section{RIC I - V.1. 1933-1984}

The Roman Imperial Coinage, London: Spink \& Son, LTD.

\section{Santosuosso, A. 2004}

Storming the Heavens, Soldiers, Emperors and Civilians in the Roman Empire, London: Pimlico.

\section{Spannagel, M. 2000}

ARMENIA RECEPTA aut CAPTA? Zur Veränderung einer augusteischen Münzlegende, XII Internationaler Numismatischer Kongress, (Berlin 1997), Akten 2, Bände I 2000: Staatliche Museen zu Berlin, 622-629.

\section{Stevenson, W. 1964}

A Dictionary of Roman Coins, Republican and Imperial, London: B. A.

\section{Strack, P. L. 1931}

Untersuchungen zur Römischen Reichsprägung des zweiten Jahrhunderts, Teil 1: Die Reichsprägung zur Zeit des Traian, Stuttgart: W. Kohlhammer.

\section{Strack, P. L. 1933}

Untersuchungen zur Römischen Reichsprägung des zweiten Jahrhunderts, Teil 2: Die Reichsprägung zur Zeit des Hadrian, Stuttgart: W. Kohlhammer.

\section{Strack, P. L. 1937}

Untersuchungen zur Römischen Reichsprägung des zweiten Jahrhunderts, Teil 3: Die Reichsprägung zur Zeit des Antoninus Pius, Stuttgart: W. Kohlhammer.

\section{Sutherland, C. H. V. 1951}

Coinage in Roman Imperial Policy $31 \mathrm{BC}-\mathrm{AD}$ 68, London: Methuen \& Co.

\section{Sutherland, C. H. V. 1987}

Roman History and Coinage 44 BC - AD 69, Oxford: Clarendon Press.

\section{Winkler 1965 - I. Winkler,}

Personificarea Daciei pe monedele Romane imperiale, Studii Clasice VII, Bucuresti (1965): 225-234. 


\section{REZIME}

PROVINCIA CAPTA I PROVINCIA FIDA ET PACATA KAO REVERSNI MOTIVI NA RIMSKOM CARSKOM NOVCU U DOBA PRINCIPATA

KLJUČne REČI: PRINCIPAT, REVERSNE PREDSTAVE, PROVINCIJE.

Reversne predstave jesu interesantan istorijski izvor koji nam dozvoljava detaljnije razmatranje aspekata spoljne i unutrašnje politike. Jedna od grupa reversnih predstava koja oslikava odnos rimljana prema pokorenim narodima, uključenim u državni provincijski sistem, su predstave personifikacija provincija. Tokom vremena ove predstave prolaze kroz različite faze, od capta do fidem, od pokorenih i još uvek neumirenih do romanizovanih i ikorporiranih $u$ administrativni, vojni i politički život Carstva. Prema tome možemo izdvojiti i dve grupe reversnih predstava na novcu: prva (capta) ilustruje rimske pobede i osvajanja novih teritorija; druga (fida et pacata) grupa u kojoj su prikazane personifikacije umirenih i više ili manje romanizovanih provincija.

\section{Provincia capta (SI. 1-50)}

Ovoj grupi reversnih predstava možemo pripisati motive trofeja i zarobljenika, kao i cara i zarobljenika. Uglavnom su reprezentovane stereotipnim ikonografskim shemama koje prikazuju osvojene trofeje i zarobljenike ili samog cara i predstavnike pokorenih naroda, koji u poniznom klečećem stavu padaju pred moćnog osvajača. Pomenuti motivi pojavljuju se na reversnim predstavama novca kao rezultat trijumfa ostvarenog uz pomoć vrlina samoga cara i snagom i sposobnostima rimske vojske. ${ }^{116}$ Zarobljenici predstavl-

116 Predstave i legende na novcu povezane su s propagandnom idejom i medjusobno su komplementarne. Legenda česće služi, ne toliko da objasni predstavu, koliko da razvije ideju koja je prikazana. Tako nailazimo na primere u kovanju Avgusta u kojima je predstava Viktorije povezana sa legendama ASIA RECEPTA (RIC I, p. 61, no. 276) i ARMENIA CAP- jaju personifikacije porobljenih naroda ili pobunjenih provincija. Svaka od ovih personifikacija određena je atributima u vidu nacionalne odeće i oružja ili za tu oblast karakterističnim biljkama i životinjama. ${ }^{117}$ Iako su postojali pokušaji kanonizacije personifikacija provincija, oni su se obično odnosili na odredjeni vremenski period i nisu sasvim ustaljeni.

Sa motivima koji predstavljaju pokorene narode susrećemo se najpre u kovanjima Cezara i potom Marka Antonija krajem Republike. Slede predstave u kovanjima: Avgusta, Flavijevaca, Trajana, Antonina, Septimija Severa i porodice, Galijena, Klaudija Gotskog, Kvintila, Aurelijana i Proba. Pojavljuju se personifikacije: Galije, Jermenije, Partije, Judeje, Germanije, Dakije, Britanije.

\section{Provincia fida et pacata (Sl. 51-100)}

Predstave provincija prolaze kroz faze od capta do fidem, što se odražava i u predstavama na novcu. Vremenom su se novoformirane provincije postepeno romanizovale i inkorporirale u administrativni, vojni i politički život Carstva, tako se i na novcu predstavljaju kao prijatelji Rima. Prvi put se susrećemo sa ovom vrstom predstava u kovanju Galbe (Španija i Galija), potom Trajana (Germanija i Arabija), da bi Hadrijan na poseban način predstavio svoj odnos do provincija u nekoliko velikih serija novca. Novo shvatanje koncepcije države, koje je promovisao, zasnivalo se ne više na primatu Italije kao gospodarice nad provincijama, već u partnerstvu svih radi zajedničke doborobiti Carstva. Ideja koju je pokušavao da objasni i sprovede zavisila je umnogome od njegove jednistvene ličnosti i kosmopolitskog duha. Nakon Hadrijanove smrti, Anto-

TA (RIC I, p. 83, no. 514). Kao što je naglašeno u tekstu, predstave iz grupe provincia capta blisko su povezane sa drugim predstavama vezanim za ostvarene pobede, kojima se u ovom radu nećemo baviti. $117 \mathrm{Na}$ primer: palma je vezana za Judeju, koplje i šestougaoni štit za Germaniju, krivi mač za Dakiju, luk, tobolac i tijara za Jermeniju, itd. 
nin Pije je takodje kovao seriju »provincije«, u želji da promoviše svoje stavove koje će zauzeti u unutrašnjoj politici, odnosno povratak tradicionalnim shvatanjima odnosa Italije i provincija. Predstave provincija kao fida pojavljuju se još i u kovanju: Komoda (Britanija), Septimija Severa (Afrika), Trajana Decija i Aurelijana (Panonije i Dakija). 

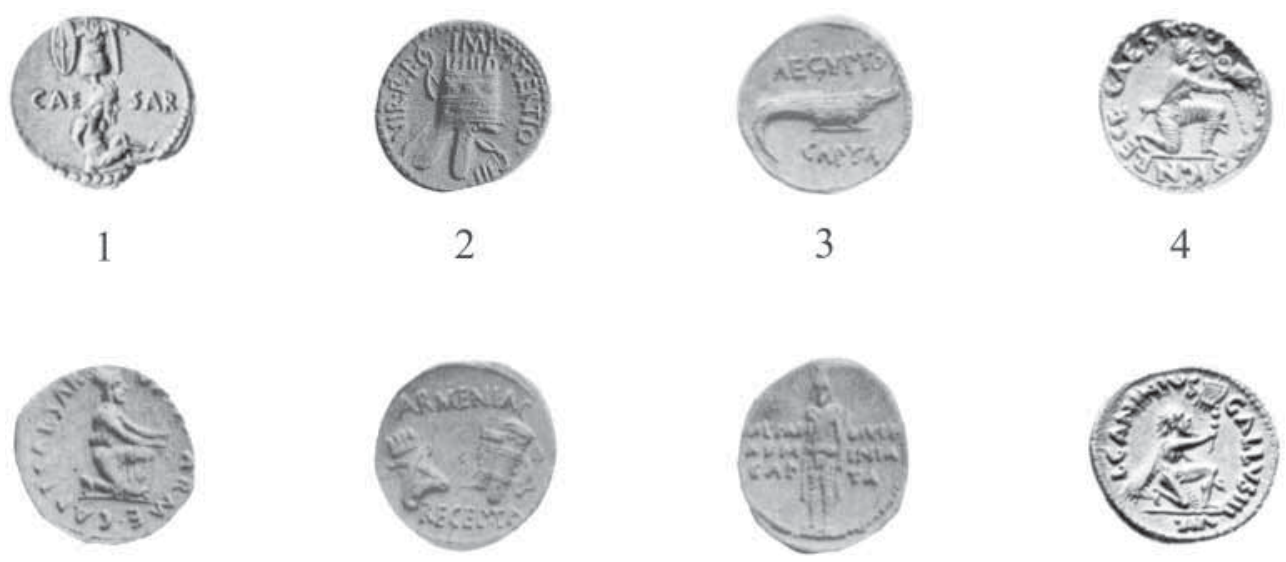

5

6

7

8

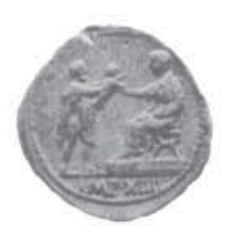

9

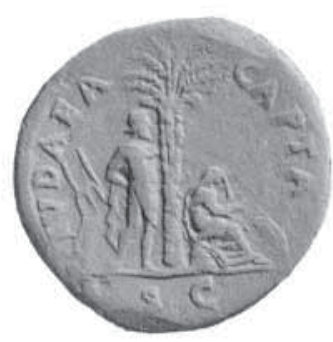

12

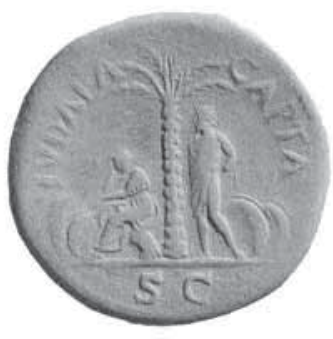

10

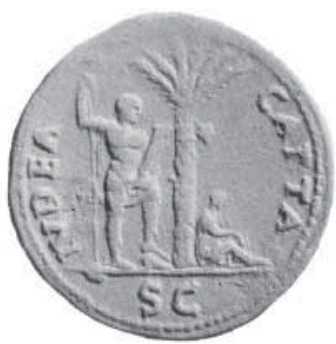

13

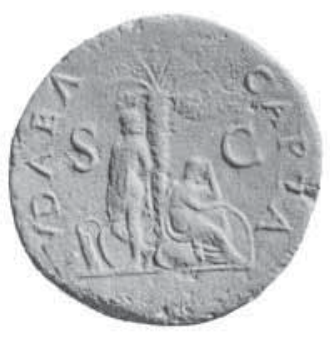

11

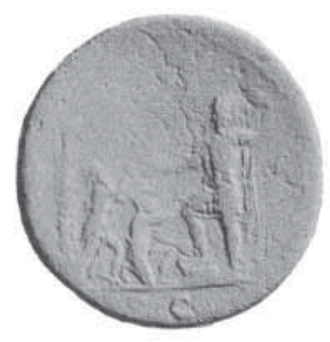

14

Fig. 1. Cezar, Sl. 2 - Marko Antonije, Fig. 3-9 - Avgust,

Fig. 10-11, 13 - Vespazijan, 1. 12-14 - Tit. 


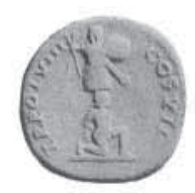

15

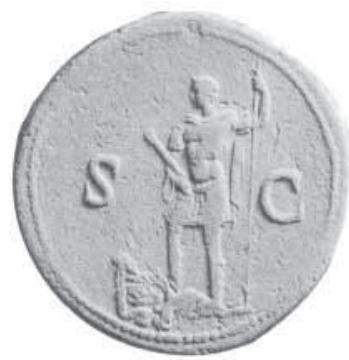

18

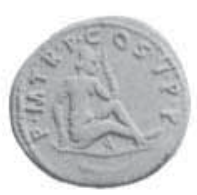

21

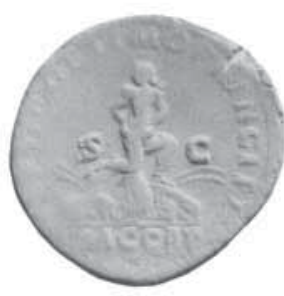

25

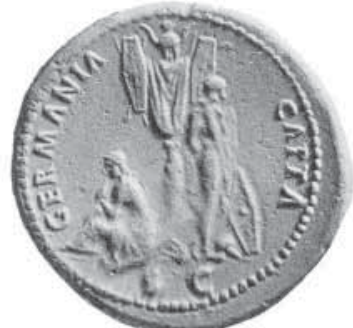

16

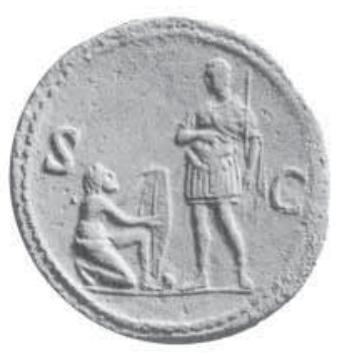

19

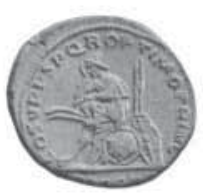

23

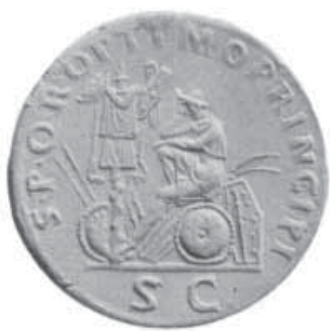

26

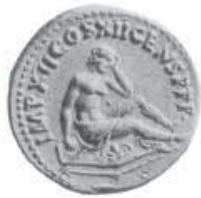

17

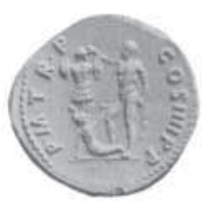

20

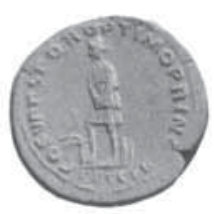

24

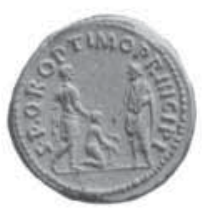

27

Fig. 15. Tit, Fig. 16-19 Domicijan, Fig. 20-27 Trajan 


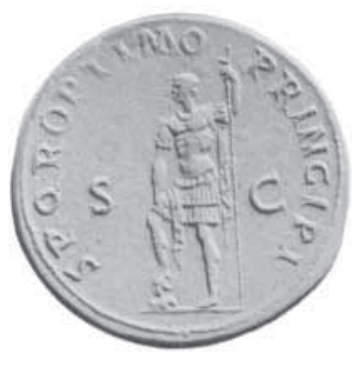

28
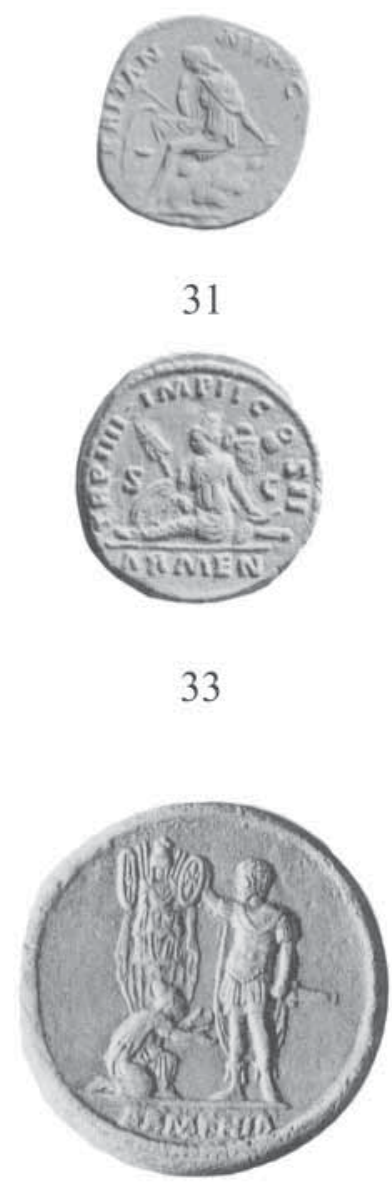

34
31

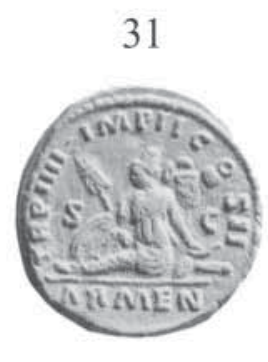

33

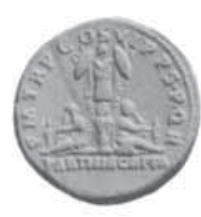

29

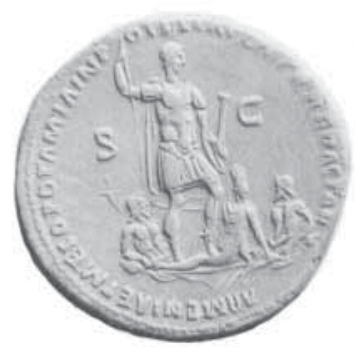

30

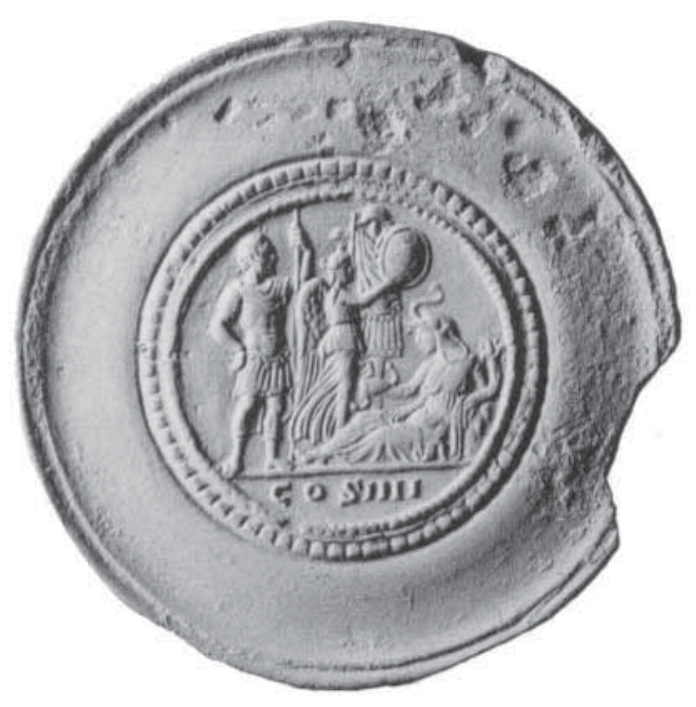

32

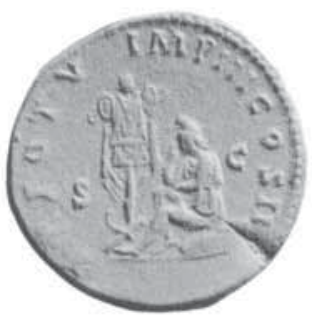

35

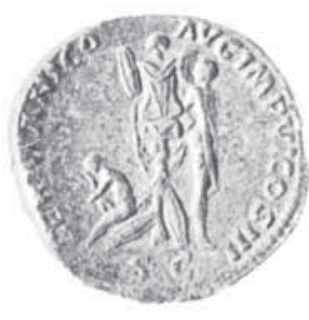

36

Fig. 28-30 Trajan, Fig. 31-32 Antonin Pije, Fig. 33-35 Lucije Ver, Fig. 36 Marko Aurelije. 


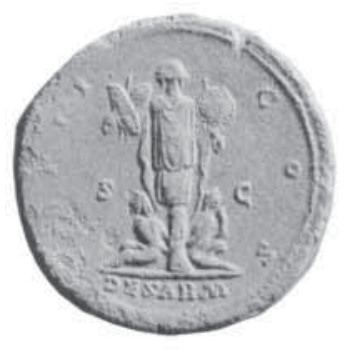

37

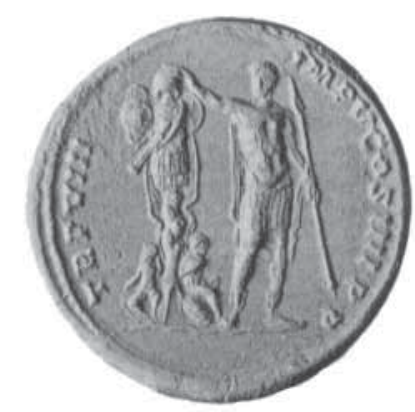

40

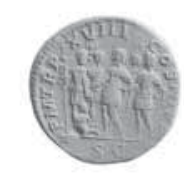

43

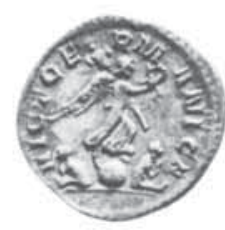

47

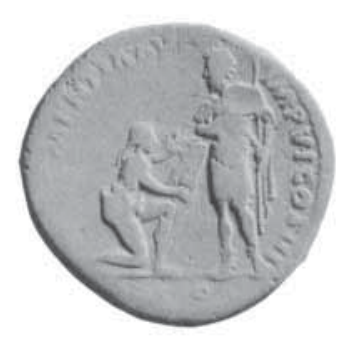

38

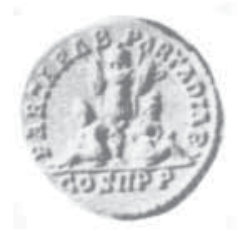

41

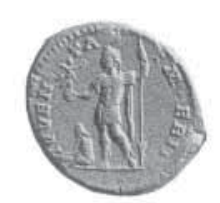

45

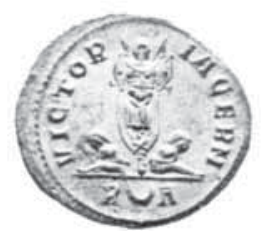

49

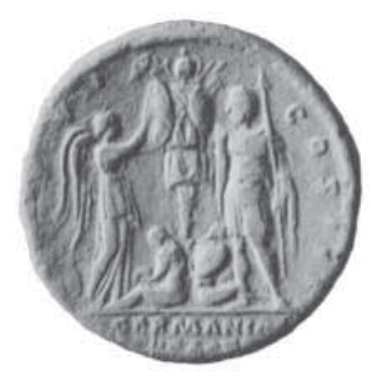

39

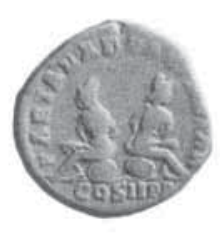

42

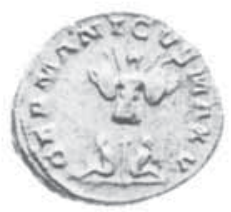

46

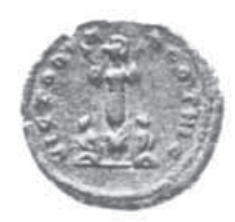

48

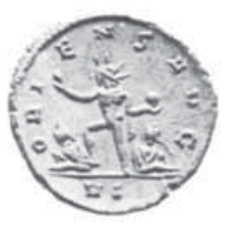

50

Fig. 37, 40 Komod, Fig. 38-39 Marko Aurelije, Fig. 41-43 Septimije Sever, Fig. 44 Geta, Fig. 45 Karakala, Fig. 46-47 Galijen, Fig. 48 Klaudije Gotski, Fig. 49 prob, Fig. 50 Aurelijan. 


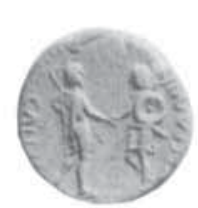

51

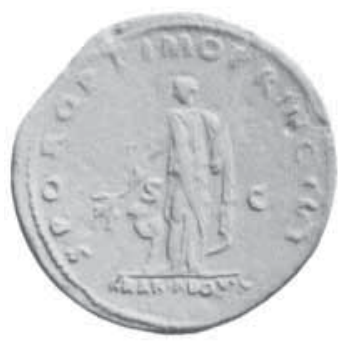

55

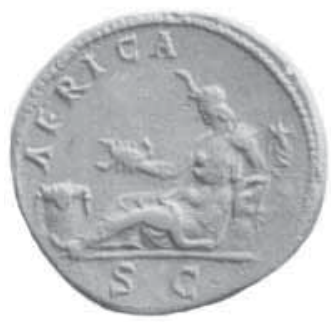

58

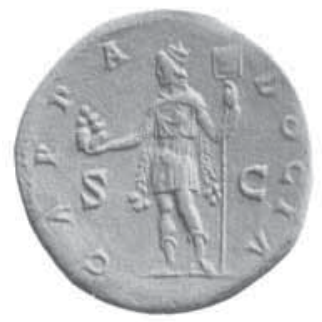

61

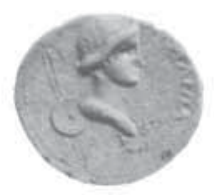

52

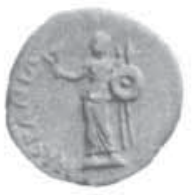

53

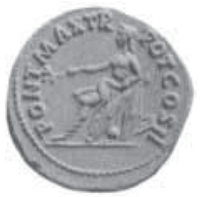

54
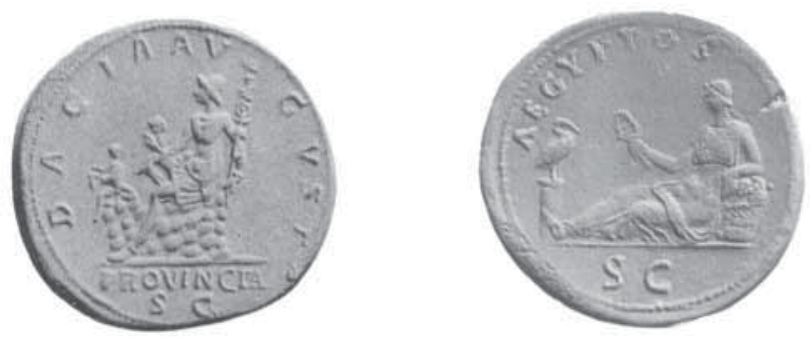

56

57
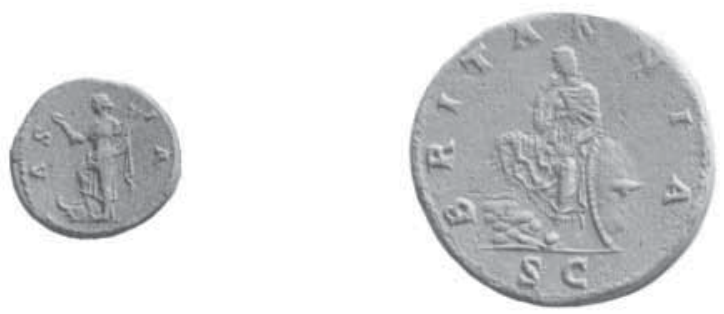

59

60
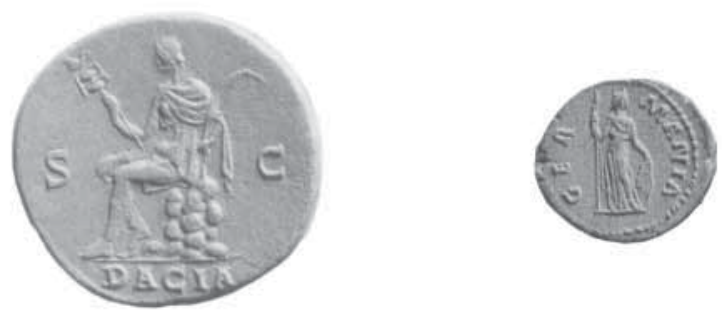

62

63

Fig. 51-53 Galba, Fig. 54-56 Trajan, Fig. 57-63 Hadrijan 


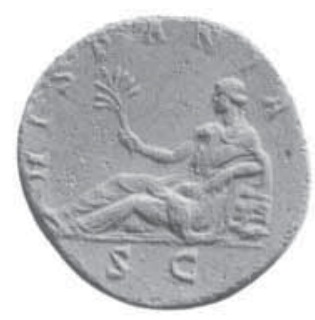

64

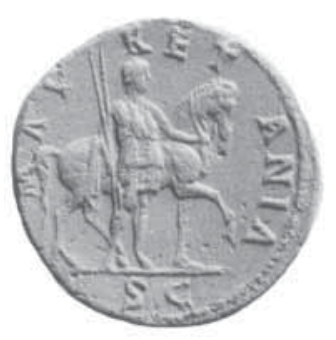

67

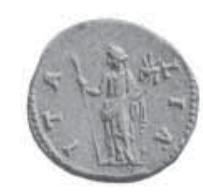

70

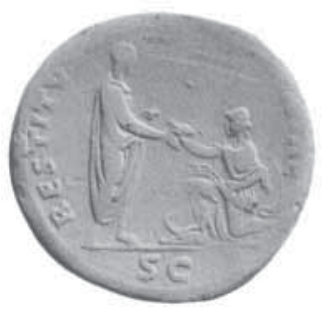

73

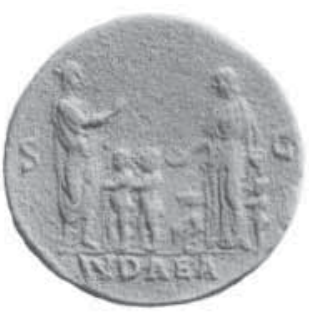

65

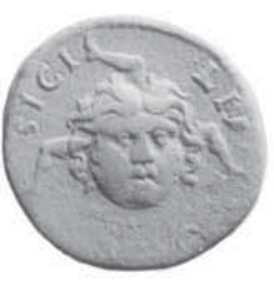

68

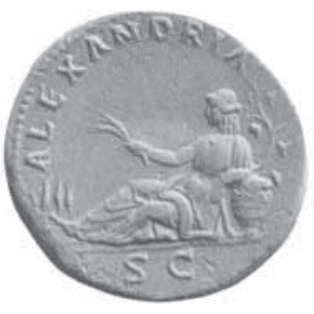

71

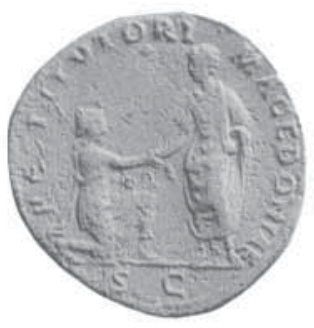

74

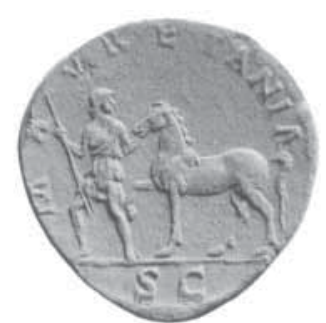

66

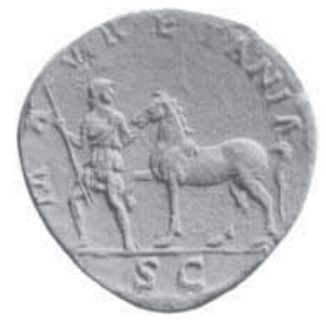

69

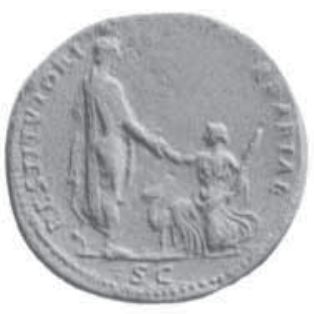

72

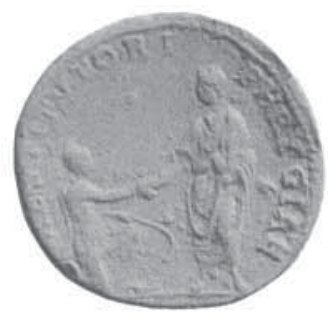

75

Fig. 64-75 Hadrijan 


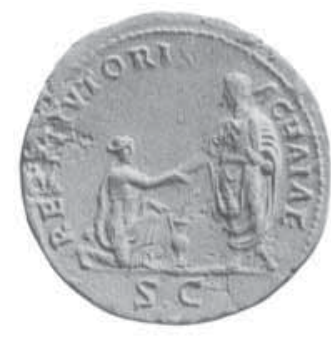

76

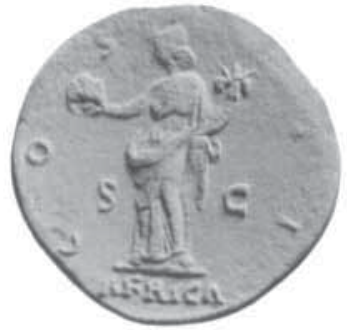

79

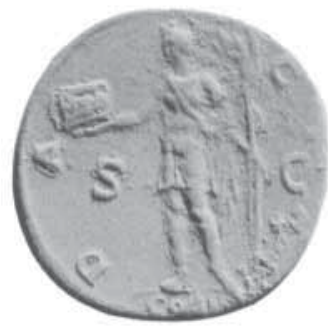

82

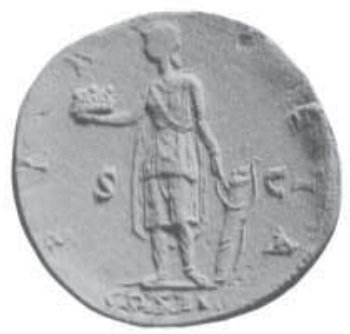

85

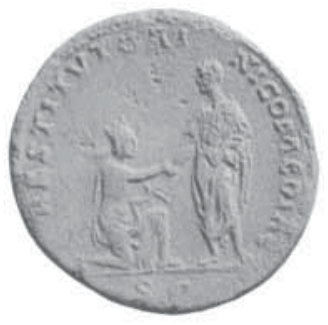

77

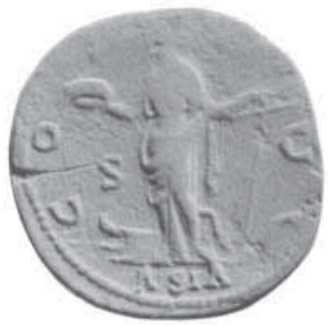

80

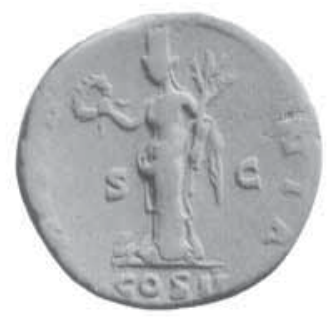

83

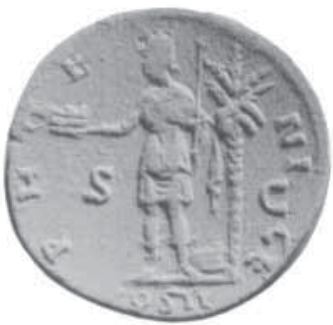

86

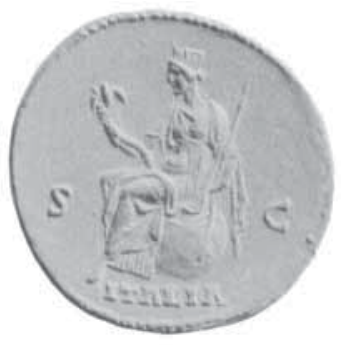

78

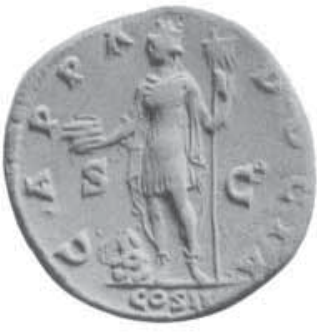

81

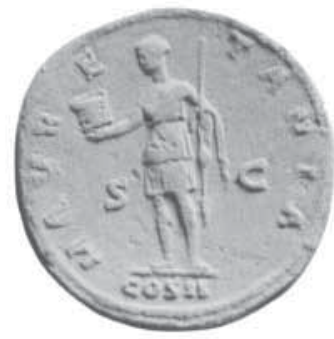

84

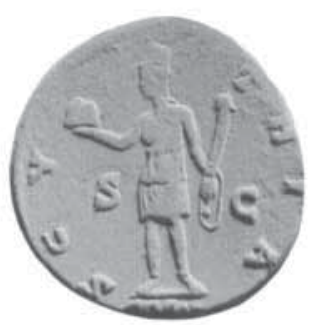

87

Fig. 76-77 Hadrijan, Fig. 78-87 Antonin Pije 

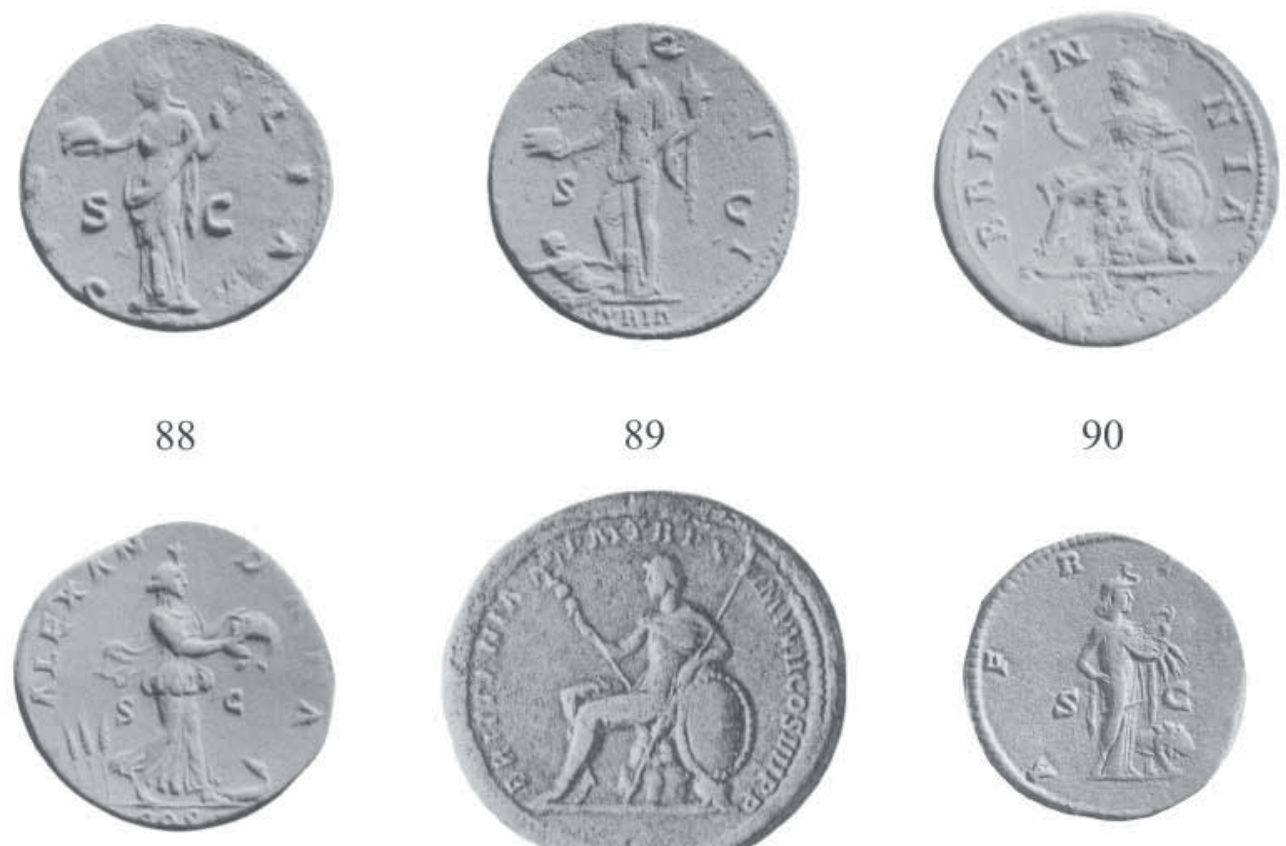

89

90

91
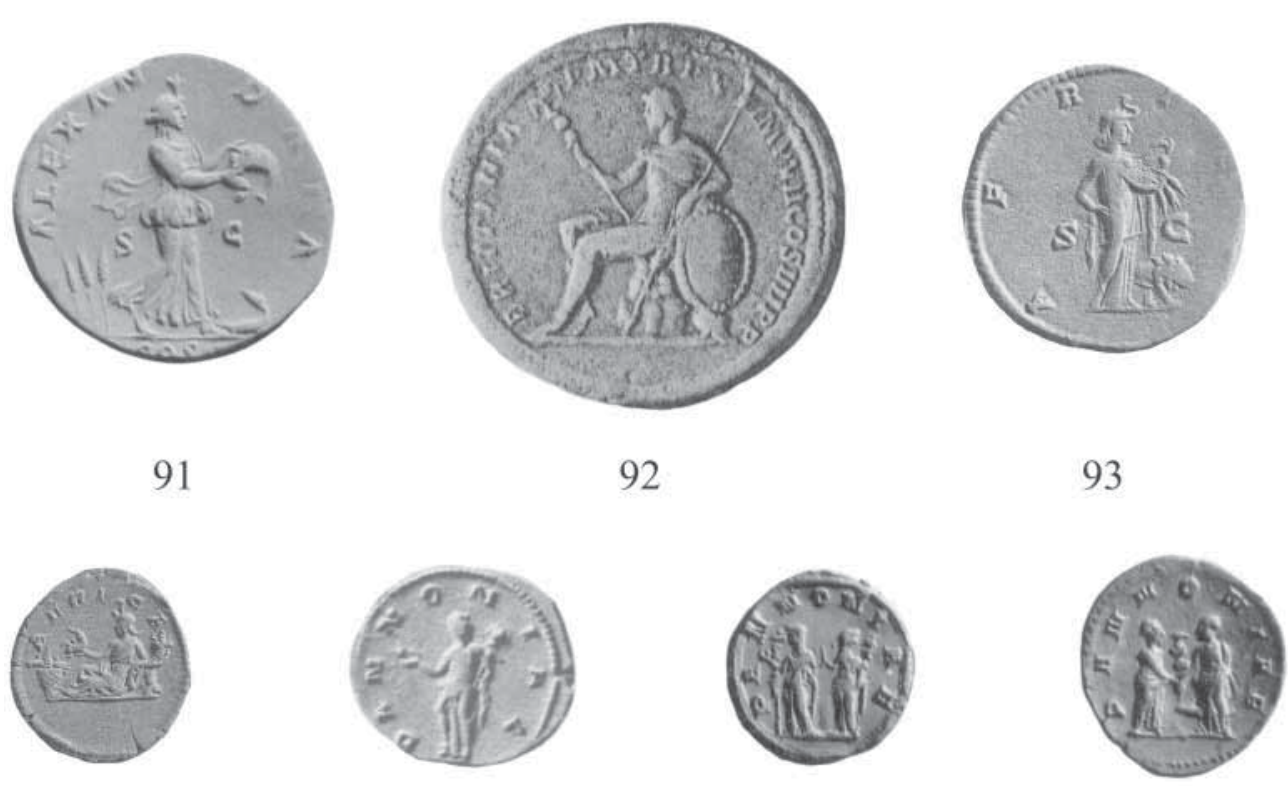

94

95

96

97

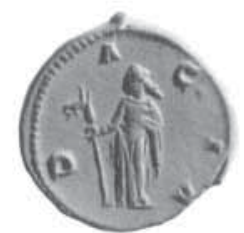

98

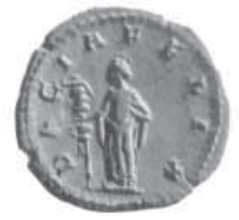

99

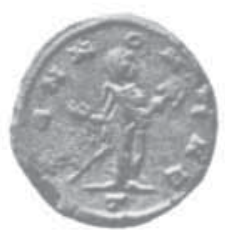

100

Fig. 88-91 Antonin Pije, Fig. 92 Komod, Fig. 93-94 Septimije,

Fig. 95-99 Trajan Decije, Fig. 100 Aurelijan 